Review article

\title{
The choroid plexus as a sex hormone target: Functional implications
}

\section{Cecília R.A. Santos a,*, Ana Catarina Duarte ${ }^{a}$, Telma Quintela a , Joana Tomás ${ }^{a}$, Tânia Albuquerque ${ }^{a}$, Fernanda Marques ${ }^{\mathrm{b}, \mathrm{c}}$, Joana Almeida Palha ${ }^{\mathrm{b}, \mathrm{c}}$, Isabel Gonçalves ${ }^{\mathrm{a}}$}

${ }^{a}$ CICS-UBI - Health Sciences Research Centre, University of Beira Interior, Av. Infante D. Henrique, 6200-506 Covilhã, Portugal

${ }^{\mathrm{b}}$ Life and Health Sciences Research Institute (ICVS), School of Health Sciences, University of Minho, Braga, Portugal

'ICVS/3B's - PT Government Associate Laboratory, Braga/Guimarães, Portugal

\section{A R T I C L E I N F O}

\section{Article history:}

Received 14 September 2016

Received in revised form 25 November 2016

Accepted 12 December 2016

Available online 18 December 2016

\section{Keywords:}

Choroid plexus

Brain barriers

Immune surveillance

Chemical surveillance

Sex hormones

Circadian rhythm

Olfactory signalling

Taste signalling

Neurogenesis

Cerebrospinal fluid

\begin{abstract}
A B S T R A C T
The choroid plexuses (CPs) are highly vascularized branched structures that protrude into the ventricles of the brain, and form a unique interface between the blood and the cerebrospinal fluid (CSF). In recent years, novel functions have been attributed to this tissue such as in immune and chemical surveillance of the central nervous system, brain development, adult neurogenesis and circadian rhythm regulation. Sex hormones $(\mathrm{SH})$ are widely recognized as modulators in several neurodegenerative diseases, and there is evidence that estrogens and androgens regulate several fundamental biological functions in the CPs. Therefore, SH are likely to affect the composition of the CSF impacting on brain homeostasis. This review will look at implications of the CPs' sex-related specificities.
\end{abstract}

(c) 2016 Elsevier Inc. All rights reserved.

\section{Contents}

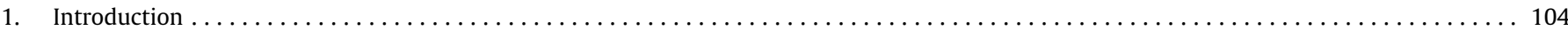

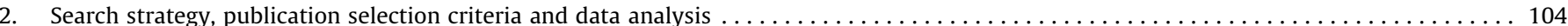

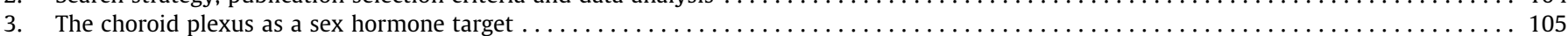

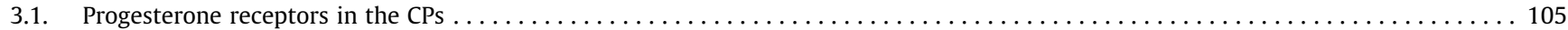

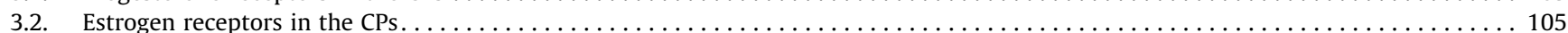

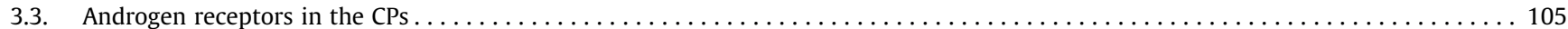

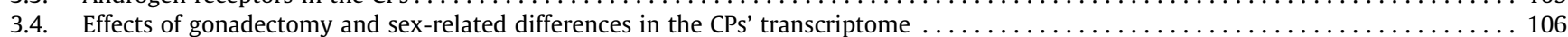

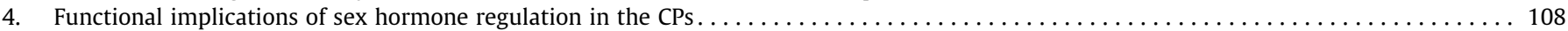

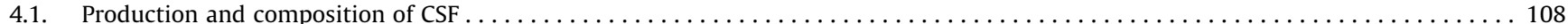

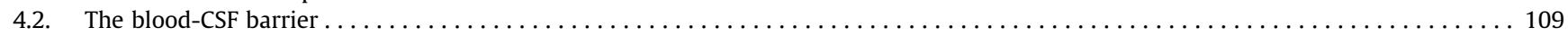

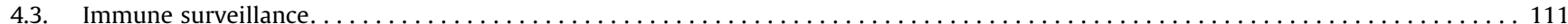

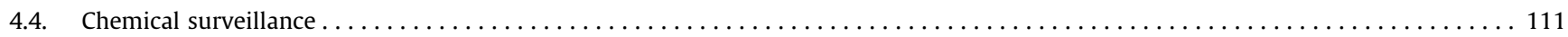

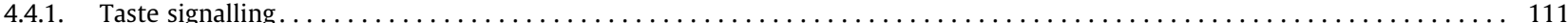

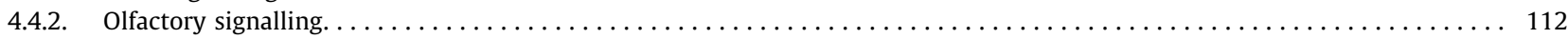

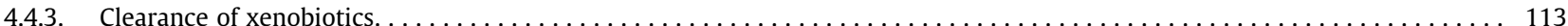

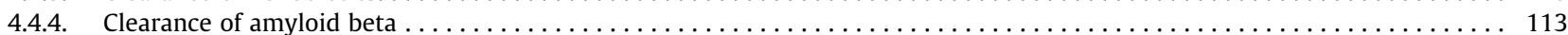

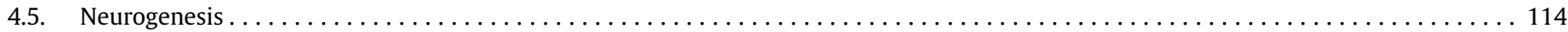

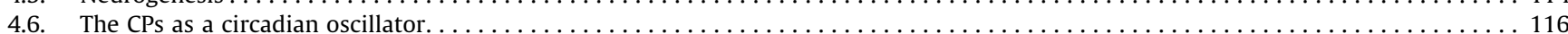

* Corresponding author at: Centro de Investigação em Ciências da Saúde, Faculdade de Ciências da Saúde, Universidade da Beira Interior, Av. Infante D. Henrique, $6200-506$ Covilhã, Portugal.

E-mail address: csantos@fcsaude.ubi.pt (C.R.A. Santos). 


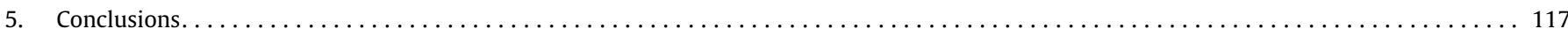

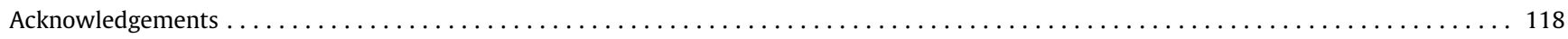

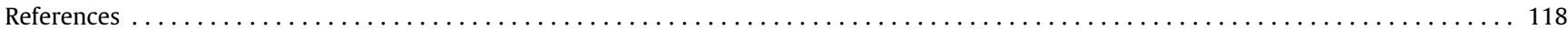

\section{Introduction}

The choroid plexuses (CPs) are highly vascularized structures, located in the ventricular system of the brain (Fig. 1). In the lateral ventricles of the mammalian brain, CPs form a sheet-like structure, whereas in the third and fourth ventricles these resemble villuslike structures. The CPs are formed by single layers of cuboidal epithelial cells laying on a basement membrane. Bellow the basement membrane, within the connective tissue, lays a network of fenestrated capillaries, fibroblasts and immune cells (e.g., mast cells, macrophages, granulocytes), and a rich extracellular matrix (Redzic and Segal, 2004). The CPs' epithelial cells (CPEC) are connected by tight junctions, adherens junctions and desmosomes, forming a sealed barrier that prevents paracellular movement of substances into and out of the brain.

CPEC also have numerous microvilli and cilia at the ventricle facing (apical) side, and extensive infolding at the blood facing (basolateral) side, thus providing a large surface for contact between the epithelium and the CSF and between the epithelium and the stroma interstitial fluid on the other side (Ghersi-Egea et al., 2009). In addition, the CPEC apical and basolateral membranes contain a wide range of transporters, channels, pumps and receptors that mediate and set the pace for the exchange of compounds between the periphery and the CSF. These are essential to fulfil the CPs' role as a source of nutrients for the brain, and also for the excretion of molecules originating from the brain metabolism.

Several fundamental functions have been attributed to the CPs and have been within the scope of recent reviews. The best known functions of CPs are CSF formation (Damkier et al., 2013), nutrient and hormone supply to the CSF and brain, clearance of deleterious compounds and waste products from brain metabolism (Johanson et al., 2011; Richardson et al., 2015; Spector et al., 2015), immune surveillance (Schwartz and Baruch, 2014), amyloid clearance (Pahnke et al., 2014; Pascale et al., 2011), and neurogenesis (Falcao et al., 2012; Johansson, 2014; Lun et al., 2015). Other emerging functions of the CPs are chemical surveillance as depicted from the presence of the taste and olfactory transduction

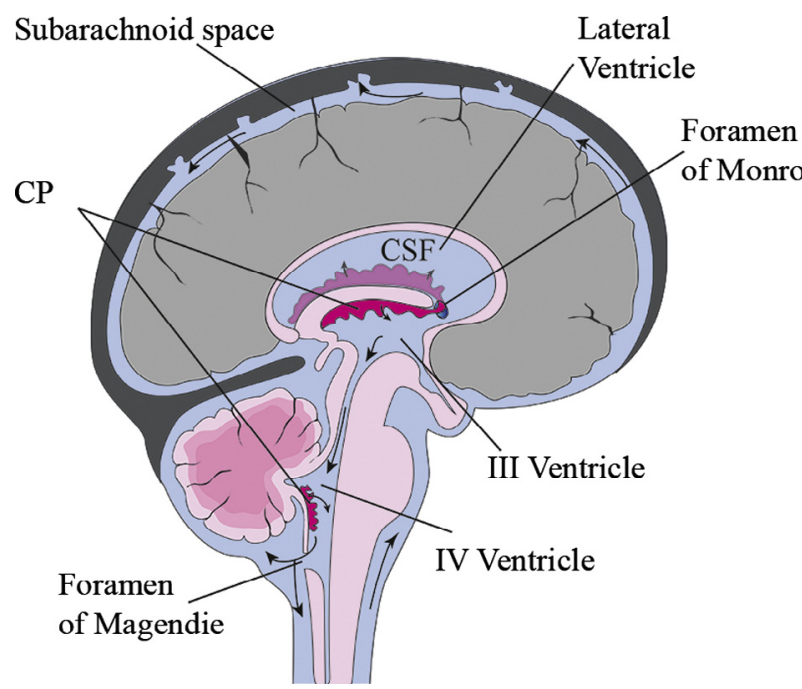

Fig. 1. The cerebrospinal fluid circulation (CP - choroid plexuses; CSF cerebrospinal fluid).

pathways in CPEC (Gonçalves et al., 2016; Tomás et al., 2016) and the potential function of the $\mathrm{CP}$ as an extra-suprachiasmatic nucleus circadian clock (Quintela et al., 2015b).

\section{Search strategy, publication selection criteria and data analysis}

Research articles were selected from PubMed database from until October 2016 on the basis of the quality of the evidence they provide following the criteria established by the Grading of Recommendations Assessment, Development and Evaluating (GRADE) working group (www.gradeworkinggroup.org). Search terms used were: brain barriers, immune surveillance, chemical surveillance, sex hormones, sex differences, estrogen, androgen, progesterone,

Table 1

Sex hormone receptors expressed in the choroid plexuses.

\begin{tabular}{|c|c|c|c|c|c|c|}
\hline $\begin{array}{l}\text { Gene } \\
\text { symbol }\end{array}$ & Gene name & $\begin{array}{l}\text { Female } \\
\text { sham }\end{array}$ & $\begin{array}{l}\text { OVX vs } \\
\text { Sham }\end{array}$ & $\begin{array}{l}\text { Male } \\
\text { sham }\end{array}$ & $\begin{array}{l}\text { OOX vs } \\
\text { Sham }\end{array}$ & $\begin{array}{l}\text { Male vs } \\
\text { Female } \\
\end{array}$ \\
\hline AR & Androgen receptor & & & & & \\
\hline Esr1 & Estrogen receptor 1 (ER alpha) & & & & & \\
\hline Esr2 & Estrogen receptor 2 (ER beta) & & & & & \\
\hline Gper & $G$ protein-coupled estrogen receptor 1 & & & & & \\
\hline PR & Progesterone receptor & & & & & \\
\hline mPR1 & Progesterone receptor membrane component 1 & & & & & \\
\hline $\mathrm{mPR} 2$ & Progesterone receptor membrane component 2 & & & & & \\
\hline
\end{tabular}

OOX - orchidectyomized male rats; OVX - ovariectomized female rats

Basal expression

$>12$

$>8$

$>4$

$<3,99$
Fold change up-regulation

$>1,5$

$>2$

$>3$
Fold change down-regulation

$>1,5$

$>2$

$>3$

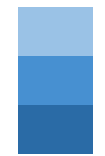


testosterone, circadian rhythm, olfactory signalling, taste signalling, neurogenesis, cerebrospinal fluid, and detoxification.

Gene expression data presented in the tables provided (Tables 1 and 4-11) were retrieved from a cDNA microarray to compare the gene expression profiling of CPs' samples from sham-operated male and female Wistar rats ( 2 months \pm 2 weeks) and male and female gonadectomised animals. Two weeks after surgery, shamoperated and castrated animals were sacrificed and their CPs were dissected from both lateral ventricles. Sampling of CPs included the connective tissue underneath. Hormonal changes were confirmed by comparing serum estradiol and testosterone levels (Quintela et al., 2013, 2016). cDNA microarray data retrieved from this study have been deposited in NCBIs Gene Expression Omnibus (http:// www.ncbi.nlm.nih.gov/geo/, accession number GSE87045).

The most relevant genes associated with each CPs' functions are presented, and their expression levels compared between males and females either sham-operated or gonadectomised. Fold change (mRNA expression ratio of male CPs versus female CPs or gonadectomised vs sham) is presented, using a P-value cut-off of 0.05 . These microarray data have been validated, by real-time reverse transcriptase-polymerase chain reaction, for 21 selected genes, to compare expression between sham males and sham females and to gonadectomised animals. In addition, simple gene expression has been confirmed for another 20 transcripts (Gonçalves et al., 2016; Quintela et al., 2013, 2016; Quintela et al., 2015a; Tomás et al., 2016).

The following sections review the available literature on the multiple functions of the CPs taking into consideration the high susceptibility of the CPs to sex hormone (SH) actions. Particular focus is given to data retrieved from this cDNA microarray study highlighting sex differences and their potential implications in diseases of the central nervous system (CNS).

\section{The choroid plexus as a sex hormone target}

There is an overall acceptance that $\mathrm{SH}$ are essential modulators of the CNS. Several brain pathologies present sex differences regarding their prevalence, symptoms and prognosis, such as Parkinson's disease (Gillies et al., 2014), Alzheimer's disease (Li and Singh, 2014), multiple sclerosis, depression and stroke (Hanamsagar and Bilbo, 2016). Both hormonal steroids released by peripheral steroidogenic glands and tissues, and steroids synthesized by neurons and glial cells (Baulieu, 1998) may contribute for these sex differences (Cosimo Melcangi and Garcia-Segura, 2010). The CPs are relevant multifunctional SH targets, containing sex hormone receptors, such as progesterone receptor (Quadros et al., 2007), alpha and beta estrogen receptor (ER) (Hong-Goka and Chang, 2004) and androgen receptor (AR) (Alves et al., 2009). Their presence features the regulation of the CPs' transcriptome and secretome by $\mathrm{SH}$. Of notice, there are no studies on whether these may underlie many of the sex-related differences seen in neurological and neurodegenerative diseases where the CPs may be involved as recently reviewed (Marques et al., 2016).

\subsection{Progesterone receptors in the CPS}

Progesterone improves the outcomes in animal models of traumatic brain injury, ischemia, spinal cord injury, peripheral nerve injury, demyelinating disease, neuromuscular disorders, and seizures through edema reduction, enhancement of neuronal survival, and regulation of inflammation and apoptosis (Deutsch et al., 2013). These neuroprotective and neuroregenerative effects are mediated by their cognate nuclear progesterone receptor (PR) or membrane bound receptors which are expressed throughout the brain (Brinton et al., 2008). Data regarding the effects of proges-
Table 2

Comparison of the number of up- and down-regulated genes in rat choroid plexuses after gonadectomy and between sham males and females.

\begin{tabular}{llll}
\hline $\begin{array}{l}\text { Fold- } \\
\text { change }\end{array}$ & $\begin{array}{l}\text { Females OVX vs } \\
\text { sham } \\
\text { No. of genes (\% of } \\
\text { genome) }\end{array}$ & $\begin{array}{l}\text { Males OOX vs sham } \\
\text { No. of genes (\% of } \\
\text { genome) }\end{array}$ & $\begin{array}{l}\text { Males sham vs } \\
\text { females sham } \\
\text { No. of genes (\% of } \\
\text { genome) }\end{array}$ \\
\hline $\begin{array}{l}\text { Up-regulated } \\
>1.5\end{array} \quad 1168(4.7 \%)$ & $426(1.7 \%)$ & $453(1.8 \%)$ \\
$\begin{array}{l}\text { Down-regulated } \\
>1.5\end{array} \quad 1328(5.3 \%)$ & $123(0.5 \%)$ & $160(0.6 \%)$ \\
\hline
\end{tabular}

OOX - orchidectomized male rats; OVX - ovariectomized female rats.

terone in CPs' gene expression or about PR expression in the CPs are still scarce. One of the genes, up-regulated in response to progesterone is that encoding for transthyretin, a major thyroid hormone and vitamin-carrier protein synthesized and secreted from the CPs into the CSF (Palha, 2002), both in vivo and in vitro (Quintela et al., 2011). Nuclear progesterone receptor has been found in the CPs (Table 1) and a membrane bound progesterone receptor (Quadros et al., 2007) is present in adult CPs and other brain regions associated with osmoregulation, suggesting a role for progesterone in the maintenance of water and ion homeostasis (Meffre et al., 2005, 2013).

\subsection{Estrogen receptors in the CPS}

Estrogens are relevant modulators of brain functions and pathways that drive reproductive behavior and cognition (Bridges, 2015; Engler-Chiurazzi et al., 2016). Despite the overall controversy around their benefits against aging and age-related neurodegeneration, several lines of evidence indicate that estrogens can be neuroprotective against stroke, traumatic brain injury and neurodegenerative diseases, such as Alzheimer's and Parkinson's. Estrogen actions are mediated by nuclear or membrane-bound ER, which are also expressed in the CPs. The exact contribution of the CPs to estrogen-mediated neuroprotection remains elusive, but this review will provide evidence that estrogens regulate several genes encoding key proteins related to neuroprotection. We have analyzed the expression of nuclear ER alpha and beta in the CPs. In rat CPEC primary cell cultures and in the Z310 cell line, ER beta seems to be more abundant than ER alpha, what is corroborated by data from the rat CPs' transcriptome (Table 1). Of notice, the CPs of ovariectomized female mice display identical levels of the two ER receptors, and supplementation with estradiol solely increases the expression of the ER beta (Quintela et al., 2009). Interestingly, the CPs from gonadectomized male rats showed increased expression of ER beta, suggesting that androgens may reduce ER beta in the CPs (Table 1 ).

\subsection{Androgen receptors in the CPS}

The AR is also present in the CPs of both male and female rodents. $5 \alpha$-dihydrotestosterone (DHT) down-regulates AR expression in the CPs of gonadectomized male and female mice (Alves et al., 2009).

Therefore, different hormonal levels, as seen between males and females and SH decline along aging are likely to set variations in CPs' gene and protein expression, including the expression of their cognate receptors, which is likely to affect CPs' functions by eliciting distinctive downstream responses in genes involved in CPs' physiology. 


\subsection{Effects of gonadectomy and sex-related differences in the CPS' transcriptome}

The influence of sex hormones in the CPs' functions may be viewed from two perspectives. That strictly originating from the sex differences when comparing males and females, and that resulting from gonadectomized female and male rats, compared with the corresponding sham-operated counterparts.

Comparison of the CPs' transcriptome of male and female sexually mature rats (Quintela et al., 2016) revealed 453 up-regulated (1.8\%) and 160 down-regulated $(0.6 \%)$ genes in male's CPs. Considering a minimum of 2.0-fold difference in expression, four downregulated pathways were identified (embryonic stem cell differentiation, the visual cycle/retinoate biosynthesis, sharing the same genes, HIPPO signalling and L-carnitine biosynthesis), whereas the only pathway differently up-regulated was that of circadian rhythm signalling. In accordance, the ten most differently expressed genes between males and females are related to neurogenesis and stem cell differentiation (frizzled-related protein 2, chemokine $\mathrm{CC}$ beta receptor 1 , insulin growth factor 2 binding protein 1), neuroprotection (GDNF receptor alpha 1; dopamine betahydroxylase), circadian rhythm (period 2 and 3, chip-derived repressor of network oscillator) and barrier function (claudin 7) (Quintela et al., 2016).

The comparison of the CPs' transcriptome of gonadectomized male and female rats to sham controls by cDNA microarrays (Quintela et al., 2013) brought forward overwhelming differences. Approximately 6000 genes corresponding to $25 \%$ of the whole rat transcriptome were differently expressed between ovariectomized female rats (OVX) and sham females among which, 1168 (4.7\%) of
Table 3

Hormonal composition of the cerebrospinal fluid.

\begin{tabular}{|c|c|c|c|}
\hline Compound & Female & Male & Reference \\
\hline Prolactin $(\mathrm{mg} / \mathrm{mL})$ & $3.99 \pm 1.01$ & $3.26 \pm 0.57$ & $\begin{array}{l}\text { Markianos } \\
\text { et al. (2010) }\end{array}$ \\
\hline Leptin $(\mathrm{pg} / \mathrm{mL})$ & $50 \pm 11$ & $185 \pm 28$ & $\begin{array}{l}\text { Page-Wilson } \\
\text { et al. (2015) }\end{array}$ \\
\hline Orexin A (pg/mL) & $90.62 \pm 15.61$ & $85.91 \pm 14.53$ & $\begin{array}{l}\text { Schmidt et al. } \\
\text { (2013) }\end{array}$ \\
\hline $\begin{array}{l}\text { Melanin-concentrating } \\
\text { hormone }(\mathrm{pg} / \mathrm{mL})\end{array}$ & $81.46 \pm 12.07$ & $87.19 \pm 10.85$ & $\begin{array}{l}\text { Schmidt et al. } \\
\text { (2013) }\end{array}$ \\
\hline Oxytocin $(\mathrm{pg} / \mathrm{mL})$ & $4.3 \pm 3$ & $3.3 \pm 3$ & $\begin{array}{l}\text { Altemus et al. } \\
\text { (1999) }\end{array}$ \\
\hline Pregnenolone $(\mathrm{pg} / \mu \mathrm{L})$ & & $0.8 \pm 0.05$ & Datta et al. \\
\hline Progesterone $(\mathrm{pg} / \mu \mathrm{L})$ & $0.39 \pm 0.01$ & $0.16 \pm 0.002$ & (1986), \\
\hline $\begin{array}{l}\text { Tetrahydroprogesterone } \\
\quad(\mathrm{pg} / \mu \mathrm{L})\end{array}$ & & $0.48 \pm 0.08$ & $\begin{array}{l}\text { Melcangi et al. } \\
\text { (2013), Molnár }\end{array}$ \\
\hline Isopregnonalone $(\mathrm{pg} / \mu \mathrm{L})$ & & $0.51 \pm 0.16$ & and Kassai- \\
\hline $\begin{array}{l}\text { Dehydroepiandrosterone } \\
\quad(\mathrm{pg} / \mu \mathrm{L})\end{array}$ & & $0.15 \pm 0.01$ & Bazsa (1997) \\
\hline Testosterone $(\mathrm{pg} / \mu \mathrm{L})$ & $0.065 \pm 0.1048$ & $0.08 \pm 0.007$ & \\
\hline $\begin{array}{l}\text { Dihydrotestosterone (pg/ } \\
\quad \mu \mathrm{L})\end{array}$ & & $0.76 \pm 0.18$ & \\
\hline $\begin{array}{l}\text { 3a-Diol = 5a-androstane- } \\
\quad 3 \mathrm{a}(\mathrm{pg} / \mu \mathrm{L})\end{array}$ & & $0.34 \pm 0.005$ & \\
\hline $17 \alpha$-Estradiol $(\mathrm{pg} / \mathrm{mL})$ & $9.4 \pm 10.2$ & & \\
\hline
\end{tabular}

the genes were up-regulated and 1328 (5.3\%) genes were down-regulated, considering fold differences above 1.5 (Table 2). Gonadectomy did not induce so profound differences in the transcriptome of males' CPs compared to sham animals, but still 15\% (549 genes) of the rat CPs' transcriptome experienced variations corresponding to 426 (1.7\%) up-regulated genes, and $123(0.5 \%)$

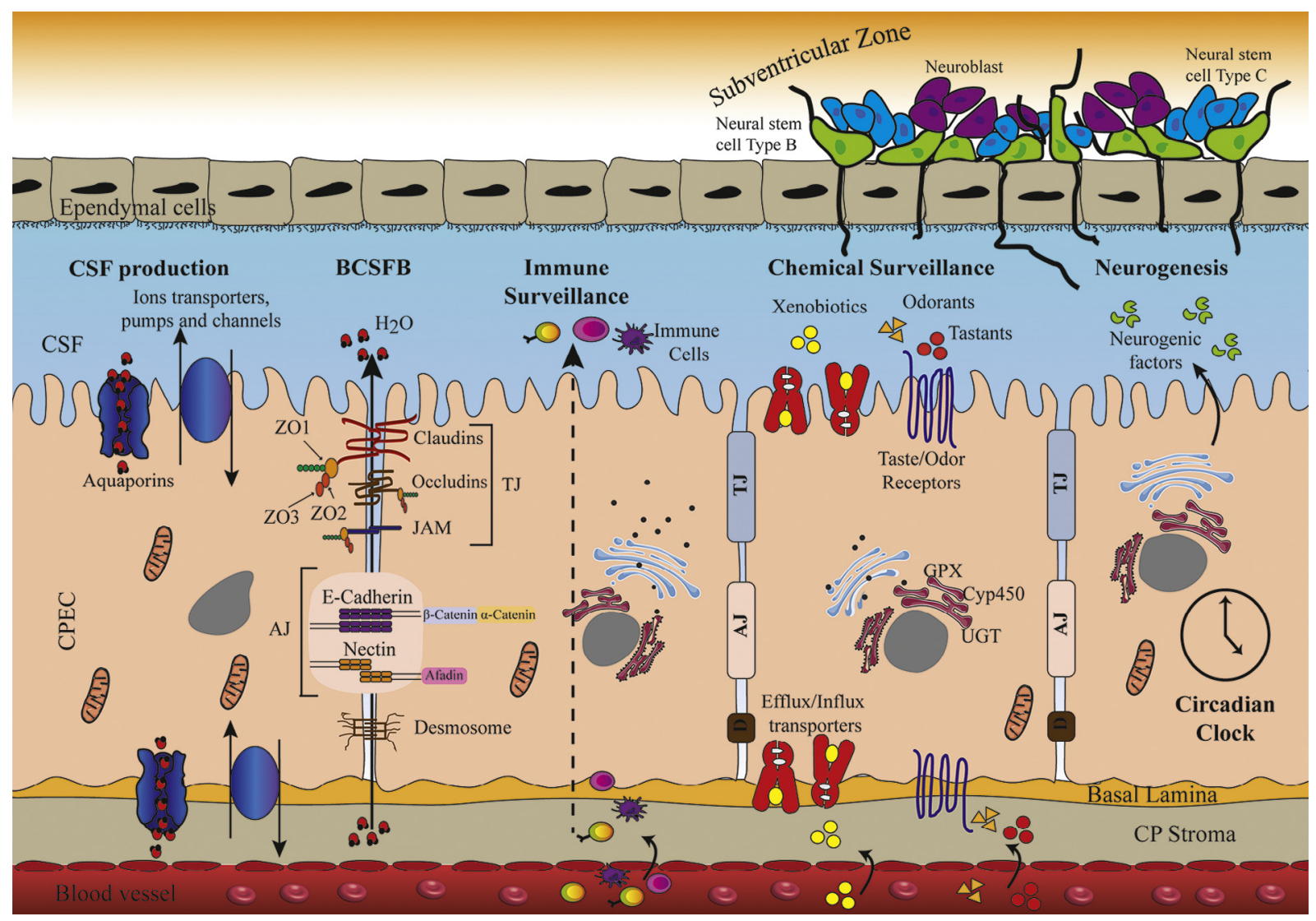

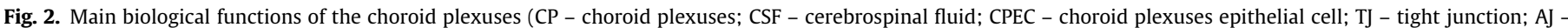

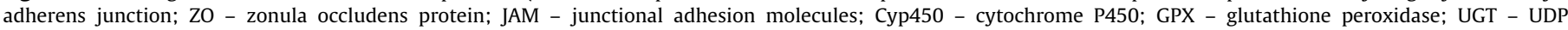
glucuronosyltransferase). 
Table 4

Genes expressed in the choroid plexuses associated with cerebrospinal fluid production and osmoregulation.

\begin{tabular}{|c|c|c|c|c|c|c|}
\hline $\begin{array}{l}\text { Gene } \\
\text { symbol }\end{array}$ & Gene name & $\begin{array}{l}\text { Female } \\
\text { sham }\end{array}$ & $\begin{array}{l}\text { OVX vs } \\
\text { Sham }\end{array}$ & $\begin{array}{l}\text { Male } \\
\text { sham }\end{array}$ & $\begin{array}{l}\text { OOX vs } \\
\text { Sham }\end{array}$ & $\begin{array}{l}\text { Male vs } \\
\text { Female }\end{array}$ \\
\hline & Pumps and channels & & & & & \\
\hline Agt & Angiotensin & & & & & \\
\hline Ace & Angiotensin I converting enzyme 1 & & & & & \\
\hline Ace2 & Angiotensin I converting enzyme 2 & & & & & \\
\hline Agtr1a & Angiotensin II receptor, type la & & & & & \\
\hline Aqp1 & Aquaporin 1 & & & & & \\
\hline Aqp4 & Aquaporin 4 & & & & & \\
\hline Aqp 5 & Aquaporin 5 & & & & & \\
\hline Aqp 7 & Aquaporin 7 & & & & & \\
\hline Aqp9 & Aquaporin 9 & & & & & \\
\hline Avp & Arginine vasopressin & & & & & \\
\hline Avprlb & Arginine vasopressin receptor $1 B$ & & & & & \\
\hline Calb1 & Calbindin 1 & & & & & \\
\hline Calb2 & Calbindin 2 & & & & & \\
\hline & $\mathrm{Cl}^{-}$channels & & & & & \\
\hline Clcn 1 & Chloride channel 1 & & & & & \\
\hline $\mathrm{Clcn} 2$ & Chloride channel 2 & & & & & \\
\hline $\mathrm{ClcnKb}$ & Chloride channel $\mathrm{Kb}$ & & & & & \\
\hline & k+ channels & & & & & \\
\hline Kcnk16 & Potassium channel, subfamily K, member 16 & & & & & \\
\hline Kcnk18 & Potassium channel, subfamily K, member 18 & & & & & \\
\hline & $\mathrm{Na}+/ \mathrm{Ca} 2+$ exchangers & & & & & \\
\hline Slc8a2 & Solute carrier family $8(\mathrm{Na}+/ \mathrm{Ca} 2+$ exchanger $)$, member 2 & & & & & \\
\hline & $\mathrm{Na}+/ \mathrm{H}+$ Exchangers & & & & & \\
\hline Slc9a8 & Solute carrier family $9(\mathrm{Na}+/ \mathrm{H}+$ exchanger $)$, member 8 & & & & & \\
\hline & $\mathbf{N a}+\mathbf{k}+\mathbf{A T P a s e}$ & & & & & \\
\hline Atp1a2 & ATPase, $\mathrm{Na}+/ \mathrm{K}+$ transporting, alpha 2 polypeptide & & & & & \\
\hline & Anion transporters & & & & & \\
\hline Slc26a10 & Solute carrier family 26, member 10 & & & & & \\
\hline & Peptides & & & & & \\
\hline Aldoc & Aldolase C, fructose-bisphosphate & & & & & \\
\hline Apoa1 & Apolipoprotein A-I & & & & & \\
\hline Apoe & Apolipoprotein $E$ & & & & & \\
\hline $\mathrm{B} 2 \mathrm{~m}$ & Beta-2 microglobulin & & & & & \\
\hline $\mathrm{C} 3$ & Complement $\mathrm{C} 3$ & & & & & \\
\hline Colla1 & Collagen, type I, alpha 1 & & & & & \\
\hline Col10a1 & Collagen, type $X$, alpha 1 & & & & & \\
\hline Cst3 & Cystatin $C$ & & & & & \\
\hline Ctsd & Cathepsin D & & & & & \\
\hline Hert & Orexin $A$ & & & & & \\
\hline Oxt & Oxytocin & & & & & \\
\hline Timp1 & TIMP metallopeptidase inhibitor 1 & & & & & \\
\hline $\operatorname{Ttr}$ & Transthyretin & & & & & \\
\hline
\end{tabular}

OOX - orchidectyomized male rats; OVX - ovariectomized female rats

Basal expression

$>12$

$>8$

$>4$

$<3,99$
Fold change up-regulation

$>1,5$

$>2$

$>3$
Fold change down-regulation

$>1,5$

$>2$

$>3$

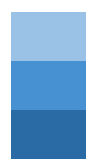

down-regulated genes when compared to sham animals (considering fold differences above 1.5; Table 2). The top five pathways differently affected by the $\mathrm{SH}$ background were olfactory and taste transduction, metabolism of xenobiotics by cytochrome P450, pentose and glucuronate interconversions, ascorbate and aldarate metabolism, steroid hormone biosynthesis and circadian rhythm.
These data suggest that establishment of circadian rhythms and synthesis of peptides implicated in neurogenesis and neuronal survival may be seminal functions of the CPs that remarkably differ between males and females and are affected by the SH background. Other functions as protein synthesis and trafficking, metabolism and barrier function seem also to be differently driven by $\mathrm{SH}$ differences (Quintela et al., 2016) as discussed below. 


\section{Functional implications of sex hormone regulation in the CPs}

The following sections provide an overview of possible functional implications of the observed sex differences in the CPs' transcriptome.

\subsection{Production and composition of CSF}

A major function of the CPs is CSF formation (Fig. 2), which regulates homeostasis in the CNS, providing physical protection and buoyancy for the brain and spinal cord, regulation of intracranial pressure, waste removal and a supportive environment (Damkier et al., 2013).

The CPs produce about $80 \%$ of the CSF, while the remaining $20 \%$ comes from the interstitial fluid of the brain for which there is a considerable contribution of the blood-brain-barrier. The rate of CSF formation in humans is $\sim 500-600 \mathrm{~mL}$ in $24 \mathrm{~h}$ and the total CSF volume is $90-150 \mathrm{~mL}$ in adults meaning that it is replaced three to four times a day (Damkier et al., 2013). Several differences between the CSF of males and females have been reported, from CSF flow dynamics and density (Schiffer et al., 1999; Schmid Daners et al., 2012) to its actual composition (Table 3).

The CSF formation at the CPs encompasses the passive filtration of fluid across the highly permeable capillary endothelium that irrigates the CPs' stroma and a regulated secretion across the single-layered CPs' epithelia sealed by tight junctions at the apical cell membranes. Water transport across the CPs' epithelia is controlled by membrane transporters within the epithelium and water channels like aquaporin 1 and ion transporters at the apical membrane $\left(\mathrm{K}^{+} / \mathrm{Cl}^{-}\right.$cotransporter and $\mathrm{Na}^{+} / \mathrm{K}^{+}$-ATPase) (Brinker et al., 2014). There are no major sex-differences or effect of gonadectomy on the expression of the major CPs' aquaporins 1 and 4. Despite an overall expression in several tissues of the body, neither aquapor- ins 5 and 9 have been described in the brain or CPs before (Direito et al., 2016), but we detected both by cDNA microarrays. Aquaporins 7 and 9 are described to contribute to water, glycerol and urea diffusion (Badaut, 2010). Interestingly, aquaporins 5 and 7 gene expression were increased in OVX animals (Table 4).

The driving force for fluid secretion across CPEC is the osmotic gradient created by the active flux of ions from across the epithelial layer, which is accompanied by the movement of water. The movement of ions is mediated by transporters and ion channels, which are asymmetrically distributed between the apical and basolateral membranes (Redzic and Segal, 2004). Chloride, potassium and sodium channels also seem to be sensitive to $\mathrm{SH}$ in the CPs. We found increased expression levels of the gene encoding for chloride channels 1, 2 and $K B$ in OVX compared to sham animals. Dysfunction of chloride channel 1 gene has been associated with epilepsy and Huntington's disease (Imbrici et al., 2015). Solute carrier family 9, member $8, \mathrm{a} \mathrm{Na}^{+} / \mathrm{H}^{+}$exchanger, increased in males' CPs in comparison to females' and the solute carrier family 26 , member 10 increased upon OVX (Table 4). Differences in the expression of the $\mathrm{Na}^{+} / \mathrm{H}^{+}$exchangers between males and females have also been reported in mice renal brush-border membranes where the exchange rates are higher in males than in females. Castration of male mice led to a decrease in $\mathrm{Na}^{+} / \mathrm{H}^{+}$exchange to values found in females (Macković et al., 1986).

Many of the pivotal hormones, receptors and enzymes, that regulate systemic water and electrolyte homeostasis, such as aldosterone, angiotensin, and arginine vasopressin, are also expressed in the CPs and differently regulated according to the SH background, as angiotensin II receptor type $1 \mathrm{a}$ and angiotensin converting enzyme 2, both reduced upon OVX (Table 4).

Other important feature of the CSF is its composition in organic compounds like vitamins (e.g., ascorbic acid, methyltetrahydrofalate), hormones and proteins (Merched et al., 1998; Serot et al.,

Table 5

Genes expressed in the choroid plexuses associated with its barrier function

\begin{tabular}{|c|c|c|c|c|c|c|}
\hline $\begin{array}{l}\text { Gene } \\
\text { symbol } \\
\end{array}$ & Gene name & $\begin{array}{l}\text { Female } \\
\text { sham }\end{array}$ & $\begin{array}{l}\text { OVX vs } \\
\text { Sham }\end{array}$ & $\begin{array}{l}\text { Male } \\
\text { sham }\end{array}$ & $\begin{array}{l}\text { OOX vs } \\
\text { Sham } \\
\end{array}$ & $\begin{array}{l}\text { Male vs } \\
\text { Female } \\
\end{array}$ \\
\hline Cdh1 & Cadherin 1 & & & & & \\
\hline $\mathrm{Cdh} 22$ & Cadherin 22 & & & & & \\
\hline Ctnna2 & Catenin alpha 2 & & & & & \\
\hline Ctnnd2 & Catenin delta 2 & & & & & \\
\hline Cldn 1 & Claudin 1 & & & & & \\
\hline Cldn2 & Claudin 2 & & & & & \\
\hline Cldn 3 & Claudin 3 & & & & & \\
\hline Cldn5 & Claudin 5 & & & & & \\
\hline Cldn6 & Claudin 6 & & & & & \\
\hline Cldn7 & Claudin 7 & & & & & \\
\hline Cldn 9 & Claudin 9 & & & & & \\
\hline Cldn 11 & Claudin 11 & & & & & \\
\hline Cldn 12 & Claudin 12 & & & & & \\
\hline Cldn19 & Claudin 19 & & & & & \\
\hline Cldn22 & Claudin 22 & & & & & \\
\hline Ocln & Occludin & & & & & \\
\hline $\mathrm{ZO}-1$ & Zonula occludens 1 & & & & & \\
\hline
\end{tabular}

OOX - orchidectyomized male rats; OVX - ovariectomized female rats

Basal expression

$>12$

$>8$

$>4$

$<3,99$
Fold change up-regulation

$>1,5$

$>2$

$>3$
Fold change down-regulation

$>1,5$

$>2$

$>3$

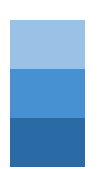


Table 6

Genes expressed in the choroid plexus associated with immune surveillance.

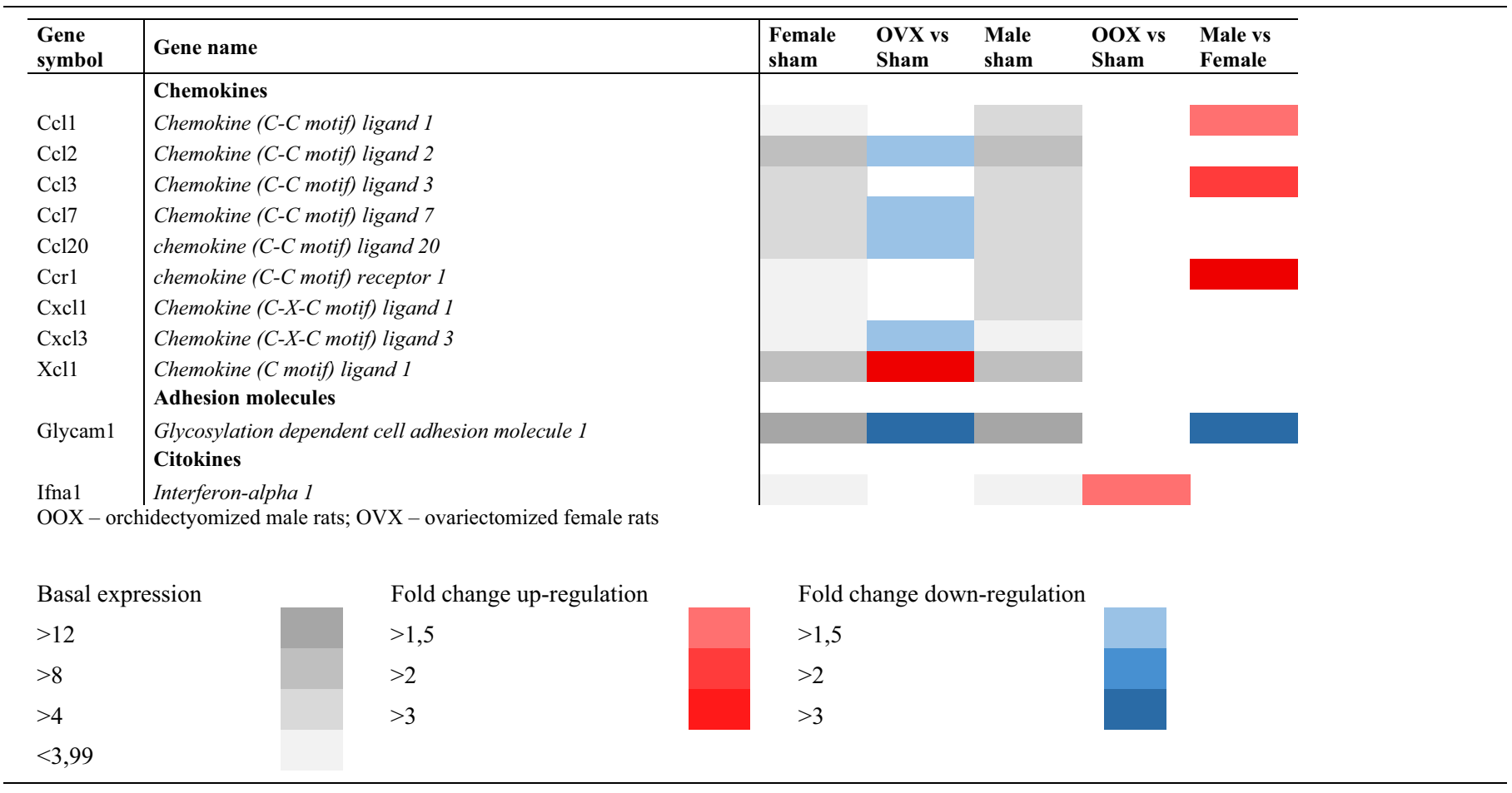

2001). The relative contribution of CPs' cells to the presence of many of these compounds is still uncertain. Differences in the CSF composition between sexes have also been assessed in several frameworks, but there is still a lot to unveil.

Recently, we have compared the most abundant proteins in the CSF between males and females, and between gonadectomized male and female rats and sham animals, by 2-D DIGE followed by LC-MS/MS identification. Only changes in abundance greater than 1.5 times (up or down) within the 95\% confidence level ( $p<0.05$ ) were considered (Quintela et al., 2016). We found that prostaglandin D2 synthase (1.77-fold), TTR and apolipoprotein AI (both with -1.63 -fold) and fructose-bisphosphate aldolase $\mathrm{C}$ and insulin like growth factor binding protein $2(-1.52$ and -1.43 -fold, respectively) are less abundant in the CSF samples from male than in female rats (Quintela et al., 2016). Interestingly, gonadectomy in males but not in females induced changes in the CSF proteome despite the greater differences found in the transcriptome of gonadectomised females compared to sham (Quintela et al., 2013). In the CSF of orchidectomized male rats (OOX), transferrin (1.7-fold); TTR (1.63- to 2.14-fold); apolipoprotein E (1.72- to 1.96-fold); insulin like growth factor binding protein 2 (1.65- to 1.96-fold); prostaglandin D2 synthase (1.95- to 2.47-fold) and Apolipoprotein A-I (1.81-fold) were more abundant than in sham animals, whereas complement C3 (-1.49-fold) was less abundant in the OOX group when compared to sham animals (Quintela et al., 2016).

Many other peptides previously identified in the supernatant of CPEC enriched cultures (Thouvenot et al., 2006) are indeed encoded by genes with high expression in the CPs' transcriptome (Table 4), suggesting that they are secreted by the CPs, although some are typically genes expressed by mesenchymal cells and could also represent a contribution of genes of stromal cells. Among these, we have identified increased gene expression of collagen type X alpha 1, upon OVX and in males in comparison to females. An opposite trend for collagen type I regulation has been reported in the rat ventricular myocardium where significantly higher $(303 \%, \mathrm{P}<0.01)$ mRNA levels occur in the female heart compared with the male heart (Rosenkranz-Weiss et al., 1994). Transcription of the gene encoding for tissue inhibitor of metalloproteinase inhibitor 1 was decreased in the CPs of OOX animals.

Other sex differences reported in the CSF composition refer to orexin A, which is elevated in women compared to men $(90.62 \pm 15.61 \mathrm{pg} / \mathrm{mL}$ vs. $85.91 \pm 14.53 \mathrm{pg} / \mathrm{mL}$ ) (Schmidt et al., 2013). Oxytocin, prolactin and leptin (Altemus et al., 1999; Markianos et al., 2010) and CD4+ T(Reg), are also higher in the CSF of women than in men (Tejera-Alhambra et al., 2012). Noticeably orexin A, oxytocin and prolactin may also originate from the CPs, as we found expression of the genes encoding these proteins in CPs; however, only the gene encoding for prolactin was differently expressed being higher in sham females than in OVX females or males (Table 10). These observations suggest that the CPs may also contribute to the homoeostasis of food intake.

\subsection{The blood-CSF barrier}

The junctional complexes in CPs are composed by intercellular tight junctions between cells, which are the most apical component of the epithelial junctional complex, adherens junctions and desmosomes (Fig. 2). Tight junctions regulate the diffusion of water, ions, and other small molecules through the paracellular space between neighbouring cells, and ensure cell polarity by precluding the movement of components of the apical membrane to the basolateral membrane. Tight junctions are composed by occludin, claudins (i.e. claudin 1, 2, 3 and 11), and junctional adhesion molecules $\mathrm{A}$ and $\mathrm{C}$. These proteins bind the scaffolding proteins zonula occludens 1,2 and probably zonula occludens 3 , connecting neighbouring cells to each other's actin cytoskeleton and recruit cytosolic molecules which are involved in cell signalling. Of all transmembrane proteins in tight junctions, claudins and particularly claudin 1 , determine the selective size, charge, and conductance properties of the paracellular pathway. Adherens junctions are formed by the homophilic interaction of cis homodimers of 
the transmembrane protein E-cadherin which bind members of the p120- and $\beta$-catenin family that through binding to $\alpha$-catenin, link E-cadherin to the epithelial actin cytoskeleton (Schneeberger and Lynch, 2004; Tietz and Engelhardt, 2015; Van Itallie and Anderson, 2006).

The expression of adherens and tight junction proteins in the blood-CSF barrier (BCSFB) has been extensively studied. Adherens junction proteins, cadherins and catenins were identified in the epithelial cells of CPs and in CPEC primary cultures. Kratzer et al., 2012 analysed the expression of 14 members of the claudin family in CPs. Of all tested, claudins $1,-2$, and -3 showed the highest levels of expression, particularly claudin 1 . We found that claudins $5,-6$, $9,-10,-11,-12,-19$ and -22 are also expressed in CPs (Quintela et al., 2013) as well as occludin and zonula occludens 1. Interestingly, the expression of tight junction proteins fluctuates during the various phases of development; that of claudins 2, -9 and -22 increase along development while that of claudins 3 and -6 decrease. Therefore, an active barrier function starts early in development as deduced from the expression of tight junction proteins in CPs (Coisne and Engelhardt, 2011; Ek et al., 2012; Kratzer et al., 2012, 2013; Wolburg et al., 2001) and is unlikely to be less effective at this stage. The only report on the regulation of key elements

Table 7

Genes expressed in the choroid plexuses associated with chemical surveillance.

\begin{tabular}{|c|c|c|c|c|c|c|}
\hline $\begin{array}{l}\text { Gene } \\
\text { symbol }\end{array}$ & Gene name & $\begin{array}{l}\text { Female } \\
\text { sham }\end{array}$ & $\begin{array}{l}\text { OVX vs } \\
\text { Sham }\end{array}$ & $\begin{array}{l}\text { Male } \\
\text { sham }\end{array}$ & $\begin{array}{l}\text { OOX vs } \\
\text { sham }\end{array}$ & $\begin{array}{l}\text { Male vs } \\
\text { female }\end{array}$ \\
\hline & Taste signalling & & & & & \\
\hline Gnat3 & Guanine nucleotide binding protein, alpha transducing 3 & & & & & \\
\hline Gnb3 & Guanine nucleotide binding protein, beta polypeptide 3 & & & & & \\
\hline Itpr3 & Inositol 1,4,5-triphosphate receptor, type 3 & & & & & \\
\hline Plcb2 & Phospholipase C, beta 2 & & & & & \\
\hline Scnnlg & Sodium channel, nonvoltage-gated 1 gamma & & & & & \\
\hline Trpm5 & Transient receptor potential cation channel, subfamily $M$, member 5 & & & & & \\
\hline Tas1r1 & Taste receptor, type 1, member 1 & & & & & \\
\hline Tas 1r3 & Taste receptor, type 1, member 3 & & & & & \\
\hline Tas2r109 & Taste receptor, type 2, member 109 & & & & & \\
\hline Tas 2 r124 & Taste receptor, type 2, member 124 & & & & & \\
\hline Tas2r134 & Taste receptor, type 2, member 134 & & & & & \\
\hline Tas 2 r137 & Taste receptor, type 2, member 137 & & & & & \\
\hline Tas $2 \mathrm{r} 40$ & Taste receptor, type 2, member 40 & & & & & \\
\hline & Olfactory signalling & & & & & \\
\hline Ac3 & Adenylate Cyclase 3 or III & & & & & \\
\hline Clca41 & Chloride channel calcium activated 4-like & & & & & \\
\hline Clca5 & Chloride channel calcium activated 5 & & & & & \\
\hline Cng2 & Cyclic nucleotide gated channel 2 & & & & & \\
\hline Cnga3 & Cyclic nucleotide gated channel alpha 3 & & & & & \\
\hline Cnga4 & Cyclic nucleotide gated channel alpha 4 & & & & & \\
\hline Cngb1 & Cyclic nucleotide gated channel beta 1 & & & & & \\
\hline $\begin{array}{l}\text { GNAL or } \\
\text { Gaolf }\end{array}$ & $\begin{array}{l}\text { Guanine Nucleotide Binding Protein (G Protein), Alpha Activating } \\
\text { Activity Polypeptide, Olfactory Type }\end{array}$ & & & & & \\
\hline Gucalb & Guanilate cyclase activator $1 B$ & & & & & \\
\hline Pdc & Phosducin & & & & & \\
\hline Prkg2 & Protein Kinase, cGMP-dependent, type II & & & & & \\
\hline Olr19 & Olfactory receptor 19 & & & & & \\
\hline Olr476 & Olfactory receptor 476 & & & & & \\
\hline Olr522 & Olfactory receptor 522 & & & & & \\
\hline Olr540 & Olfactory receptor 540 & & & & & \\
\hline Olr611 & Olfactory receptor 611 & & & & & \\
\hline Olr806 & Olfactory receptor 806 & & & & & \\
\hline Olr812 & Olfactory receptor 812 & & & & & \\
\hline Olr1105 & Olfactory receptor 1105 & & & & & \\
\hline Olr1266 & Olfactory receptor 1266 & & & & & \\
\hline Olr1382 & Olfactory receptor 1382 & & & & & \\
\hline Olr1701 & Olfactory receptor 1701 & & & & & \\
\hline
\end{tabular}

OOX - orchidectyomized male rats; OVX - ovariectomized female rats

\section{Basal expression}

$>12$

$>8$

$>4$

$<3,99$
Fold change up-regulation

$$
>1,5
$$

$>2$

$>3$

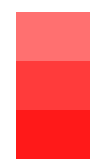

Fold change down-regulation

$>1,5$

$>2$

$>3$ 
of intercellular junctions by SH refers to the endothelium where DHT and E2 enhance tight junction function by decreasing paracellular permeability and increasing occludin levels (Sumanasekera et al., 2007). We found that the mRNA encoding several elements of the junctional complexes are modulated by SH (Table 5). Claudin 1 was reduced upon OVX, and claudin 5 expression was enhanced in males' CPs, whilst claudin 7 expression diminished in males in comparison to females. Claudin 12 expression diminished in the CPs of OOX. No major differences were seen among the other cadherins and claudins. It is of major interest to assess if these differences in gene expression do translate into protein expression and their impact on the paracellular transport of cells and compounds across the BCSF between sexes.

\subsection{Immune surveillance}

For a long time the brain was considered isolated from the immune system. The assumption of an immune-privileged system was supported by the existence of a barrier system, among other features. While these barriers protect the brain from the fluctuations of blood components that are direct triggers of neuronal function (e.g. amino acids that function as neurotransmitters), it is now clear that they are much more than obstacles to the passage of molecules and cells. Of relevance, these barriers are now being considered themselves as relevant places for the dialogue between the immune system and the brain (Fig. 2). The CPs respond to rapid and to prolonged peripheral inflammatory stimuli (Marques et al., 2009a, 2009b, 2009c, 2012). This response is particularly of interest since it displays features not present in the basal state, such as the ability to alter the homeostasis of iron metabolism, and influences the composition of the CSF (Marques et al., 2009a). Also reported is the participation of the CPs in the adaptive immunity, which is critical for the maintenance of brain function. Under physiological conditions, this activity has been associated with CD4+ T cells specific for brain self-antigens. It has been proposed that CNSspecific T cells shape brain function via the CPs, and apparently this immunological control may be lost with aging, particularly with immune senescence, with a concomitant compromise of brain function (Baruch et al., 2013; Baruch and Schwartz, 2013).

In aging and in Alzheimer's disease mouse models, a type I interferon (IFN-I)-dependent gene expression profile, similar to that found in aged human brains, was identified (Baruch et al., 2014; Mesquita et al., 2015). This response was induced by brain-derived signals, present in the CSF (Baruch et al., 2014). Blocking IFN-I signalling within the aged brain partially restored cognitive function and hippocampal neurogenesis and reestablished the IFN-II-dependent CPs' activity that is lost in aging (Baruch et al., 2014). Based on these data it seems that the CPs exhibit an aging-induced IFN-I signature which has a negative impact on cognitive function (Baruch et al., 2014; Schwartz and Baruch, 2014). It has been hypothesized that $\mathrm{CD} 4^{+}$effector memory $\mathrm{T}$ cells, within the CPs' stroma, regulate leukocyte trafficking through the CPs' epithelia. Interferon-type II, together with tumour necrosis factor- $\alpha$, induces immune cell trafficking molecules through the activation of their own receptors in CPs' epithelial cells (Baruch et al., 2015; Kunis et al., 2013).

Of relevance, little is known about the influence of SH concerning the expression, in the CPs, of molecules known to regulate the immune function. However, it is clear that the CPs transcriptome immune signature also depends on the hormonal status. This is especially true for the expression of some chemokines like chemokine ( $\mathrm{C}$ motif) ligand 1, that was increased about 2-fold upon OVX, while chemokines (C-C motif) such as ligand 2, ligand 7, ligand 20 , and chemokine ( $\mathrm{C}-\mathrm{X}-\mathrm{C}$ motif) ligand 3 were reduced to half upon OVX. Chemokine (C-C motif) ligand 1, 3 and chemokine CC beta receptor 1 expression were increased in males in comparison to females (Table 6). Sex-related differences have also been found for chemokines in several peripheral human and rodent tissues. Lower levels of chemokine ( $\mathrm{C}$ motif) ligand 1 , in females than males have been reported following injury, while chemokine ( $\mathrm{C}$ motif) ligand 3 and 20 exhibited opposite trends (Sorge and Totsch, 2016). Also the glycosylation dependent cell adhesion molecule 1 , a very abundant adhesion molecule in male and female CPs, was reduced upon OVX and also in males' CPs in comparison to females'. Interpheron alpha-1, increased upon gonadectomy in males, suggesting that it is down-regulated by androgens (Table 6). Whether these chemokines were expressed by CPEC or by immune cells in the CPs' stroma has not been further disclosed, since collection of CPs included the connective tissue underneath and the corresponding proteins are typically expressed by immune cells. Moreover, sex-related differences in the barrier junctional complexes as seen for cadherins and claudins (Table 5) may also restrain the entrance of immune cells into the CSF, so trafficking of immune cells and pathogens across the BCSFB may differ between males and females as a consequence, a possibility that deserves further investigation.

Several cytokines are also synthesized in the CPs and secreted into the CSF, with clear implications in the communication between the immune and central nervous systems (Marques et al., 2011). Here, they will be rather discussed in the context of neurogenesis (see below).

\subsection{Chemical surveillance}

The KEGG functional pathway analysis of the CPs' cDNA microarray results revealed the enrichment of a variety of physiological processes related to chemical senses, such as the taste and the olfactory transduction pathways, and to the detoxification of xenobiotics (Fig. 2).

\subsubsection{Taste signalling}

The functionality of the taste transduction pathway was recently confirmed in CPs epithelial cells, given the presence of mRNA and protein for the taste receptors type 1 member 1,2 and 3, taste receptors type 2 member 109 and 40(144) and the downstream signalling molecules $\alpha$-gustaducin, phospholipase $C$ beta2, inositol 1,4,5-triphosphate and transient receptor potential channel M5. The taste transduction pathway functionality was assessed in CPs epithelial cells, by calcium imaging, stimulated with the bitter compound D-salicin (Tomás et al., 2016), suggesting that taste receptors are involved in the chemical surveillance of the CSF and/or blood composition. Previous evidence on the regulation of this pathway by the hormonal background showed that female rats experience changes in taste bud morphology during pregnancy (Yücel et al., 2002). Moreover, the response of the parabrachial pons to bitter taste is increased in OVX rats when compared to controls (Di Lorenzo and Monroe, 1990). Hence, it seems likely that SHs affect taste and nutrient sensing both at the level of the taste buds as well as in the CNS (Faas et al., 2010; Quintela et al., 2013). In our CPs microarray study, decline of hormone levels in female rats clearly induced an up-regulation of 7 genes, including several taste receptors and phospholipase $C$ beta2 (Table 7), which were associated with taste transduction. Interestingly, this study identified differently expressed receptors of the taste receptor type 2 family (Tas2R109, Tas2R124, Tas2R134, Tas2R137, Tas2R40) responsible for the detection of bitter-tasting compounds that were up-regulated upon OVX (Chandrashekar et al., 2006), and in the case of Tas2R40, accordingly increased in males in comparison to females. Our comparative gene expression analysis provides the first evidence that the expression of taste-related genes in rat CPs is under the control of SHs (Quintela et al., 2013). Finally, the fact that this pathway is functional in CPs suggests a role for this 
epithelia as a "taste" sensor in the CNS, most likely specialized in "tasting" the chemical composition of the CSF.

\subsubsection{Olfactory signalling}

The olfactory signalling in rat CPs was first put in evidence with our comparative gene expression analysis (Quintela et al., 2013). Hormone decline in rat CPs revealed important effects in the olfactory transduction signalling, with 102 genes up-regulated and 282 down-regulated in OVX and 42 down-regulated genes in OOX. Among these differently expressed genes, most were olfactory receptors (ORs) (Quintela et al., 2013) and some examples of these ORs are represented in Table 7 (Gonçalves et al., 2016). Moreover, as indicated in Table 7, Olr 522, Olr 1266 and Olr 1701 were upregulated in males CPs in comparison to females'. The expression of these receptors was double-checked by RT-PCR. The functionality of this transduction pathway in murine CPs was recently demonstrated by electrophysiology experiments using polyamines (molecules known to be present in the CSF) as stimuli; these triggered both the cAMP and the phospholipase C-inositol 1,4,5triphosphate signalling pathways (Gonçalves et al., 2016). There is evidence that SHs elicit alterations in olfactory function in humans (Doty and Cameron, 2009), and steroid hormones such as androstenone and androstadienone were identified as ORs ligands (Keller et al., 2007). Initially identified in the sensory neurons of the olfactory epithelium, recent studies showed that different tissues also express olfactory receptors, including brain (cortex and hippocampus), gut, muscle, kidney, placenta and cornea (Braun et al., 2007; Griffin et al., 2009; Grison et al., 2014; Otaki et al., 2004; Pluznick et al., 2009; Quintela et al., 2015a). The growing number of traditionally non-olfactory tissues with olfactory receptors expression strongly suggest that these receptors must play other physiological roles and can detect also non-volatile molecules in body fluids. Such may be the case for the CPs, as potential sensors of the CSF chemical composition. Other interesting down-regulated gene in the CPs of OVX is phosducin. Phosducin is a protein highly abundant in the retinal photoreceptor cells and in pinealocytes (Schulz, 2001), which has been suggested to modulate cilia of olfactory neurons (Boekhoff et al., 1997). All these results suggest that olfactory-like chemosensory signalling, together with taste transduction, may be essential components of

Table 8

Genes expressed in the choroid plexuses associated with xenobiotic metabolism and detoxification.

\begin{tabular}{|c|c|c|c|c|c|c|}
\hline $\begin{array}{l}\text { Gene } \\
\text { symbol }\end{array}$ & Gene name & $\begin{array}{c}\text { Female } \\
\text { sham }\end{array}$ & $\begin{array}{c}\text { OVX vs } \\
\text { Sham }\end{array}$ & $\begin{array}{l}\text { Male } \\
\text { sham }\end{array}$ & $\begin{array}{c}\text { OOX vs } \\
\text { Sham }\end{array}$ & $\begin{array}{c}\text { Male vs } \\
\text { Female }\end{array}$ \\
\hline & Phase I drug metabolizing enzymes & & & & & \\
\hline Adh4 & Alcohol dehydrogenase 4 (class II), pi polypeptide & & & & & \\
\hline Aldh1a7 & Aldehyde dehydrogenase family 1, subfamily A7 & & & & & \\
\hline Cyp2a2 & Cytochrome P450, family 2, subfamily a, polypeptide 2 & & & & & \\
\hline Cyp11b3 & Cytochrome P450, family 11, subfamily b, polypeptide 3 & & & & & \\
\hline Ephx1 & Epoxide hydrolase 1, microsomal & & & & & \\
\hline Ephx4 & Epoxide hydrolase 4 & & & & & \\
\hline Fmo1 & Flavin containing monooxygenase 1 & & & & & \\
\hline Fmo3 & Flavin containing monooxygenase 3 & & & & & \\
\hline Mao-a & Monoamine oxidase $A$ & & & & & \\
\hline & Phase IIdrug metabolizing enzymes & & & & & \\
\hline Gstm5 & Glutathione S-transferase, mи 5 & & & & & \\
\hline Sult5a1 & Sulfotransferase family $5 \mathrm{~A}$, member 1 & & & & & \\
\hline Sult6b1 & Sulfotransferase family, cytosolic, $6 B$, member 1 & & & & & \\
\hline Ugtla6 & UDP glucuronosyltransferase 1 family, polypeptide A6 & & & & & \\
\hline & Antioxidant enzymes & & & & & \\
\hline Gpx6 & Glutathione peroxidase 6 & & & & & \\
\hline & Efflux transporters & & & & & \\
\hline Abcal & ATP-binding cassette, subfamily A (ABC1), member 1 & & & & & \\
\hline Abca2 & ATP-binding cassette, subfamily A (ABC1), member 2 & & & & & \\
\hline Abca7 & ATP-binding cassette, subfamily A (ABC1), member 7 & & & & & \\
\hline Abcbla & ATP-binding cassette, sub-family $B(M D R / T A P)$, member $1 a$ & & & & & \\
\hline Abcblb & ATP-binding cassette, subfamily $B(M D R / T A P)$, member $1 b$ & & & & & \\
\hline Abcc1 & ATP-binding cassette, subfamily $C(C F T R / M R P)$, member 1 & & & & & \\
\hline Abcc3 & ATP-binding cassette, subfamily $C(C F T R / M R P)$, member 3 & & & & & \\
\hline Slc6d1 & Solute carrier organic anion transporter family, member $6 d 1$ & & & & & \\
\hline $\operatorname{Slc} 22 \mathrm{a} 7$ & Solute carrier family 22, member 7 & & & & & \\
\hline Slc22a8 & Solute carrier family 22, member 8 & & & & & \\
\hline Slc $22 \mathrm{a} 23$ & Solute carrier family 22, member 23 & & & & & \\
\hline
\end{tabular}

OOX - orchidectyomized male rats; OVX - ovariectomized female rats

Basal expression

$>12$

$>8$

$>4$

$<3,99$
Fold change up-regulation

$>1,5$

$>2$

$>3$
Fold change down-regulation

$>1,5$

$>2$

$>3$ 
the CPs' chemical surveillance apparatus, to detect alterations in the CSF composition, and to elicit responses to modulate and maintain brain homeostasis.

\subsubsection{Clearance of xenobiotics}

There is growing evidence that drug detoxification mechanisms are present throughout the brain, with a more intense activity at the interface between the blood and the CSF (Choudhuri et al., 2003; Strazielle and Ghersi-Egea, 1999). The CPs are known for their capacity to clear potentially harmful blood- and brain-born compounds due to the action of a wide variety of protein transporters, drug metabolizing enzymes and antioxidant systems which together have impact on the clearance of xenobiotics from the brain (Choudhuri et al., 2003; Ghersi-Egea et al., 2006).

The clearance of xenobiotics comprises three phases; the first two involving the enzymatic conversion into more hydrophilic metabolites that lead ultimately to the inactivation and elimination of these exogenous compounds (phase III). Studies with CPs' extracts have shown that genes encoding for phase I (functionalization) and phase II (conjugation) metabolizing enzymes are expressed in CPs, with some of these enzymes reaching the expression levels seen in the liver, the principal site of xenobiotic metabolism in the body (Ghersi-Egea et al., 1994).

Phase I enzyme components present in CPs include monoamine oxidases, epoxide hydrolases, flavin-containing monooxygenases, NADPH-cytochrome P450 reductase and members of the cytochrome P450s family. These enzymes inactivate exogenous compounds, such as pesticides and carcinogenic molecules, and increase their susceptibility for phase II metabolizing enzymes (Strazielle et al., 2004). Phase II enzymes produce even less toxic and more polar compounds which enable them to be readily excreted in urine and bile. These conjugation activities are catalyzed mainly by UDP-glucuronosyl transferases, sulfotransferases and glutathione S-transferases. Finally, metabolism products are extruded by several efflux transporters allocated in CPs, which include mainly the ATP-binding cassette transporter families, and the organic anion and cation transporters of the solute carrier families (Ek et al., 2010; Ghersi-Egea et al., 2006). In addition to these detoxifying systems, the CPs displays a high expression of antioxidant enzymes that inactivate the reactive and potentially deleterious molecules that can be formed as a result of phase I oxidative and reductive metabolism and of phase II reactions. These include superoxide dismutases, catalase and glutathione peroxidases (Kratzer et al., 2013). Previous studies in the choroidal epithelium have shown the presence of all three classes of enzymes, displaying higher activities when compared to other brain structures (GhersiEgea et al., 1994; Philbert et al., 1995).

In our CPs' microarray study, the genes coding for phase I (e.g. alcohol dehydrogenase 4, class II, pi polypeptide; aldehyde dehydrogenase family 1 , subfamily a7; epoxide hydrolase 1 , microsomal; monoamine oxidase A; flavin containing monooxygenase 3 ), phase II (e.g. UDP glucuronosyltransferase 1 family, polypeptide A6; glutathione s-transferase, mu 5) and phase III (e.g. ATPbinding cassette, subfamily C, CFTR/MRP, member 1 ; solute carrier family 22, member 23) metabolizing enzymes as well as for antioxidant enzymes (e.g. Gpx6) were found, which is in accordance with previous findings (Kratzer et al., 2013; Martínez et al., 2001; Strazielle et al., 2004).

Although the role of CPs in xenobiotics clearance has gained significance over the last decades, there are still some issues to be explored. For instance, researchers found some differences between primates and rodents regarding expression of the cytochromes P450 enzymes that should be taken into consideration when translating data to the human scenario (Ek et al., 2015).

Recent studies also investigated the presence of an effective barrier mechanism during gestation and postnatal period, demon- strating that some mechanisms are probably more relevant during early stages of development, as their expression is higher in the embryo than in the adult. The observed profiles suggest that the CPs detoxification pathways appear to be efficient in the developing brain, putting in evidence a possible age dependent expression of such enzymatic systems (Ek et al., 2015; Kratzer et al., 2013; Richard et al., 2001).

Of notice, in the context of the present review, is the sex influence in the response to xenobiotics, since these may underlie some of the sex-differences observed in response to pharmacological treatments (Soldin et al., 2011; Soldin and Mattison, 2009).

Sex-dependent differences have been demonstrated for several cytochromes P450 isozymes as well as for sulfotransferases, glutathione S-transferases, and glucuronyltransferases, in rodents (rats and mice) and in humans (Mugford and Kedderis, 1998; Yang et al., 2012). The best examples of sex differences in xenobiotic metabolism come from the rat in which adult male liver metabolize many compounds at higher rates than females (Mugford and Kedderis, 1998) what is also influenced by age (Dhir et al., 2006). In mice, on the contrary, female liver has the higher metabolic capacity, but the differences are not as great as those seen in rats (Clodfelter et al., 2006). In other species, including humans, sex differences in xenobiotic metabolism in the liver are less pronounced.

No studies have to date reported sex- or hormonal-related differences in such enzymatic systems in the CPs. However, while comparing gene expression in the CPs of female and male rats we detected sex differences in the expression of genes associated with cytochrome P450 mediated metabolism (Table 8). These results are in accordance with previous studies showing a sexual dimorphism of these enzymes in the rat and human liver (Zanger and Schwab, 2013). The expression levels of some enzymes (e.g. cytochrome P450, family 2, subfamily a, polypeptide 2 (Сyp2a2) and cytochrome $\mathrm{P} 450$, family 11 , subfamily $\mathrm{b}$, polypeptide 3 (Cyp11b3)) was increased upon castration in the CPs of female rats, suggesting a down regulation of gene expression by estrogens. In addition, Cyp2a2 was increased in males in comparison to females and Cyp11b3 and sulfotransferase family 5A, member were also augmented in OOX males (Table 8).

Antioxidant enzymes activities in the brain are also of particular interest, considering that these enzymes control reactive oxygen species levels, which in turn can affect the permeability of the brain barriers (Armstead et al., 1992).

Finally, we also found up-regulation of ATP-binding cassette transporter $\mathrm{ABCC} 1$ in male rat $\mathrm{CPs}$ compared to females, while UDP glucoronosyltransferase 1 A6 was down-regulation in males compared to females and glutathione peroxidase 6 was upregulated in males vs. females (Table 8) (Quintela et al., 2013). Taken together, these findings suggest that SHs contribute to the transcriptional regulation of enzymes that are directly involved in the metabolism of xenobiotics and to the efflux transporters that participate in neuroprotective and detoxifying functions of the CPs.

Sex differences in xenobiotic metabolism may lead to major differences in susceptibility to the toxicity of a xenobiotic. For example, several studies have demonstrated differences in vulnerability to the neurotoxic effects of alcohol and methamphetamines between males and females (Alfonso-Loeches et al., 2013; Bourque et al., 2011). It is, therefore, essential to understand the sex differences in xenobiotic metabolism and in drug metabolism and disposal, as they may affect drug safety and effectiveness. This is particularly important in brain barriers regarding drugs targeting brain diseases and brain metastasis.

\subsubsection{Clearance of amyloid beta}

Brain accumulation of amyloid $\beta$ is an important hallmark of neurodegeneration in Alzheimer's disease, which may be a conse- 
Table 9

Genes expressed in the choroid plexus associated with amyloid beta synthesis and metabolism.

\begin{tabular}{|c|c|c|c|c|c|c|c|}
\hline $\begin{array}{l}\text { Gene } \\
\text { symbol }\end{array}$ & \multicolumn{2}{|c|}{ Gene name } & $\begin{array}{l}\text { Sham } \\
\text { Female }\end{array}$ & $\begin{array}{l}\text { OVX vs } \\
\text { Sham }\end{array}$ & $\begin{array}{l}\text { Male } \\
\text { Sham }\end{array}$ & $\begin{array}{l}\text { OOX vs } \\
\text { Sham }\end{array}$ & $\begin{array}{l}\text { Male vs } \\
\text { Female }\end{array}$ \\
\hline App & \multicolumn{2}{|c|}{ Amyloid beta precursor protein } & & & & & \\
\hline Bace1 & \multicolumn{2}{|c|}{ Beta-site APP-cleaving enzyme 1} & & & & & \\
\hline Bace2 & \multicolumn{2}{|c|}{ Beta-site APP-cleaving enzyme 2} & & & & & \\
\hline Psen 1 & \multicolumn{2}{|c|}{ Presenilin 1} & & & & & \\
\hline Psen2 & \multicolumn{2}{|c|}{ Presenilin 2} & & & & & \\
\hline Ncstn & \multicolumn{2}{|c|}{ Nicastrin } & & & & & \\
\hline Ager & \multicolumn{2}{|c|}{ Advanced glycosylation end product-specific receptor (RAGE) } & & & & & \\
\hline Lrp1 & \multicolumn{2}{|c|}{ Low density lipoprotein-related protein 1} & & & & & \\
\hline Lrp2 & \multicolumn{2}{|c|}{ Low density lipoprotein-related protein 2/Megalin } & & & & & \\
\hline Clu & \multicolumn{2}{|c|}{ Clusterin/Apolipoprotein $J$} & & & & & \\
\hline $\operatorname{Ttr}$ & \multicolumn{2}{|c|}{ Transthyretin } & & & & & \\
\hline Gls & \multicolumn{2}{|c|}{ Gelsolin } & & & & & \\
\hline Ide & \multicolumn{2}{|c|}{ Insulin degrading enzyme } & & & & & \\
\hline Nep & \multicolumn{2}{|c|}{ Neprilysin } & & & & & \\
\hline Ece1 & \multicolumn{2}{|c|}{ Endothelin converting enzyme 1} & & & & & \\
\hline Ece2 & \multicolumn{2}{|c|}{ Endothelin converting enzyme 2} & & & & & \\
\hline Mt1 & \multicolumn{2}{|c|}{ Metallothionein 1} & & & & & \\
\hline $\mathrm{Mt} 2$ & \multicolumn{2}{|c|}{ Metallothionein 2} & & & & & \\
\hline Mt3 & \multicolumn{2}{|c|}{ Metallothionein 3} & & & & & \\
\hline \multicolumn{8}{|c|}{ OOX - orchidectyomized male rats; OVX - ovariectomized female rats } \\
\hline \multicolumn{2}{|c|}{ Basal expression } & Fold change up-regulation & \multicolumn{3}{|c|}{ Fold change down-regulation } & & \\
\hline \multicolumn{2}{|l|}{$>12$} & $>1,5$ & \multicolumn{3}{|l|}{$>1,5$} & & \\
\hline \multicolumn{2}{|l|}{$>8$} & $>2$ & $>2$ & & & & \\
\hline \multicolumn{2}{|l|}{$>4$} & $>3$ & $>3$ & & & & \\
\hline \multicolumn{2}{|l|}{$<3,99$} & & & & & & \\
\hline
\end{tabular}

quence of amyloid $\beta$ overproduction, failure of amyloid $\beta$ transport, metabolism and clearance (Kepp, 2016). The CPs are an active site of amyloid $\beta$ clearance whose function becomes compromised in aging and in Alzheimer's disease mouse models with reduced production of CSF, diminished secretion of transthyretin, an amyloid-beta scavenger, and alterations in several transporters involved in the extrusion of amyloid beta from the CNS (AlviraBotero and Carro, 2010; González-Marrero et al., 2015; Matsumoto et al., 2015; Pascale et al., 2011). Besides, the CPs also express other relevant genes for the production of amyloid beta such as the amyloid beta precursor protein, beta-site APPcleaving enzyme 1 and 2, presenilin 1 and 2 and nicastrin (Table 9). Many of these molecules involved in brain amyloid $\beta$ surveillance (from amyloid $\beta$ production to clearance) are regulated by $\mathrm{SH}$ within the CNS and in peripheral tissues giving support to the argument that $\mathrm{SH}$ decline during aging may contribute to Alzheimer's disease onset and progression (Duarte et al., 2016). However, despite the high expression of genes involved in amyloid $\beta$ production in CPs, such as amyloid $\beta$ precursor protein, and nicastrin, no major alterations were observed between males and females or as a result of gonadectomy (Table 9). The uptake of amyloid $\beta$ peptide is mediated by specific transport mechanisms in the BCSFB, which include $A B C$ transporters, receptor for advanced glycation end products, low-density lipoprotein receptor related protein 1, megalin/low-density lipoprotein receptor related protein 2/glycoprotein 330 , and apolipoprotein $\mathrm{J} /$ clusterin. The regulation of $A B C$ transporters by $\mathrm{SH}$ in the CPs has already been discussed in the section above.

Other proteins that may be involved in amyloid $\beta$ degradation are metallothioneins either by interaction with transthyretin or by their anti-inflammatory and anti-oxidant properties (Santos et al., 2012). Most of these genes associated with amyloid $\beta$ degradation, metabolism and clearance presented little differences in its levels of expression between sexes (below 50\%), which are not indicated in Table 9. The gene encoding the enzyme neprilysin, however, decreased almost $90 \%$ in castrated females and was down-regulated in males in comparison to females, suggesting an up-regulation by ovarian hormones.

\subsection{Neurogenesis}

The differences in neurogenesis in the dentate gyrus of the hippocampus between sexes, as well as its regulation by the SH background have been under the scope of recent reviews (Galea et al., 2013; Mahmoud et al., 2016; Pawluski et al., 2009). These put in evidence that androgens increase survival of new neurons in the hippocampus of young adult males, while estrogens increase proliferation of new cells in the hippocampus of young adult females depending on the reproductive history and timing (eg. estrous cycle, reproduction, stress, and aging). Neurogenesis at the subventricular zone is also susceptible to the effects of SH (Farinetti et al. 2015; Tatar et al., 2013; Zheng et al., 2013) which determine cell survival and proliferation. It is likely that some of these differences result from the combined action of neurogenic factors regulated by $\mathrm{SH}$ in the abut CPs.

The most expressed mRNA in CPs encoding peptides with documented involvement in neurogenesis are indicated in Table 10. Data from rat and mouse CPs' cDNA microarrays (Falcao et al., 2012; Marques et al., 2011; Quintela et al., 2013) are in concert in what regards the relative abundance of these peptides. Herein we highlight differences in the relative expression of the mRNA encoding these peptides according to the SH background. 
Table 10

Genes expressed in the choroid plexuses associated with neurogenesis.

\begin{tabular}{|c|c|c|c|c|c|c|}
\hline $\begin{array}{l}\text { Gene } \\
\text { symbol }\end{array}$ & Gene name & $\begin{array}{l}\text { Female } \\
\text { sham }\end{array}$ & $\begin{array}{l}\text { OVX vs } \\
\text { Sham }\end{array}$ & $\begin{array}{l}\text { Male } \\
\text { sham }\end{array}$ & $\begin{array}{l}\text { OOX vs } \\
\text { Sham }\end{array}$ & $\begin{array}{l}\text { Male vs } \\
\text { Female }\end{array}$ \\
\hline & Growth factors & & & & & \\
\hline Igf1 & Insulin-like growth factor 1 & & & & & \\
\hline $\operatorname{Igf} 2$ & Insulin-like growth factor 2 & & & & & \\
\hline Igf $2 b p 1$ & Insulin-like growth factor $2 \mathrm{mRNA}$ binding protein 1 & & & & & \\
\hline $\operatorname{Igf} 2 \mathrm{bp} 2$ & Insulin-like growth factor $2 \mathrm{mRNA}$ binding protein 2 & & & & & \\
\hline Tgfa & Transforming growth factor alpha & & & & & \\
\hline & Cytokines and chemochines & & & & & \\
\hline Il1a & Interleukin 1 alpha & & & & & \\
\hline $\mathrm{Il1b}$ & Interleukin 1 beta & & & & & \\
\hline I17 & Interleukin 7 & & & & & \\
\hline I19 & Interleukin 9 & & & & & \\
\hline Il11 & Interleukin 11 & & & & & \\
\hline Il15 & Interleukin 15 & & & & & \\
\hline Il17c & Interleukin $17 C$ & & & & & \\
\hline Gh & Growth hormone & & & & & \\
\hline Ghr & Growth hormone receptor & & & & & \\
\hline Prl & Prolactin & & & & & \\
\hline & Wnt/ frizzled pathway & & & & & \\
\hline Frzb & Frizzled-related protein & & & & & \\
\hline Fzd1 & Frizzled homolog 1 (Drosophila) & & & & & \\
\hline Fzd2 & Frizzled homolog 2 (Drosophila) & & & & & \\
\hline Fzd3 & Frizzled homolog 3 (Drosophila) & & & & & \\
\hline Fzd6 & Frizzled homolog 6 (Drosophila) & & & & & \\
\hline Fzd7 & Frizzled homolog 7 (Drosophila) & & & & & \\
\hline Fzd8 & Frizzled homolog 8 (Drosophila) & & & & & \\
\hline Sfrp2 & Secreted frizzled-related protein 2 & & & & & \\
\hline Wnt1 & Wingless-type MMTV integration site family, member 1 & & & & & \\
\hline Wnt4 & Wingless-type MMTV integration site family, member 4 & & & & & \\
\hline Wnt5a & Wingless-type MMTV integration site family, member $5 a$ & & & & & \\
\hline Wnt5b & Wingless-type MMTV integration site family, member $5 b$ & & & & & \\
\hline & Cell diferentiation and neuroprotection & & & & & \\
\hline Dbh & Dopamine beta-hydroxylase & & & & & \\
\hline Gata4 & GATA binding protein 4 & & & & & \\
\hline Gfral & GDNF family receptor alpha 1 & & & & & \\
\hline Hoxa2 & Homeo box $A 2$ & & & & & \\
\hline & Retinoate biosynthesis & & & & & \\
\hline Rbp1 & Retinol binding protein 1 , cellular & & & & & \\
\hline Rdh5 & Retinol dehydrogenase 5 & & & & & \\
\hline Rdh10 & retinol dehydrogenase 10 (all-trans) & & & & & \\
\hline & HIPPO signalling & & & & & \\
\hline Inad12 & InaD-like 2 (Drosophila) & & & & & \\
\hline Ppmlj & Protein phosphatase $1 \mathrm{~J}$ & & & & & \\
\hline Sfn & Similar to $14-3-3$ protein sigma & & & & & \\
\hline
\end{tabular}

OOX - orchidectyomized male rats; OVX - ovariectomized female rats

Basal expression

$>12$
$>8$
$>4$
$<3,99$

Fold change up-regulation

$>1,5$

$>2$

$>3$
Fold change down-regulation

$>1,5$

$>2$

$>3$
Members of the fibroblast growth factor family, transforming growth factors, platelet derived growth factors, epidermal growth factor, and brain derived growth factor with a role on neurogenesis are all expressed in CPs (Marques et al., 2011). While the most abundant fibroblast growth factor family members (e.g. FGF-2, FGF-8 and FGF-10, epidermal growth factor and platelet derived growth factors alpha) did not show relevant differences between different SH backgrounds, other strong inducers of neurogenesis in vitro (Pastrana, 2013) seem to be sensitive to hormonal variations. Transforming growth factor alpha mRNA was reduced upon OVX and concurrently, also reduced in males in comparison to females' CPs. Previous studies report that in the mice hypothalamus 
mRNA levels of transforming growth factor alpha are also lower in males than females like in the CPs (Koshibu and Levitt, 2005).

The CPs express both insulin-like growth factors 1 and 2 and growth hormone receptor transcripts (Falcao et al., 2012; Marques et al., 2011; Quintela et al., 2013); which suggests the possibility of autocrine regulation. Both have proliferative actions in the developing cortical ventricular zone surface, and in the adult subventricular zone (Iwamoto and Ouchi, 2014; Nieto-Estévez et al., 2016; O'Kusky and Ye, 2012; Ziegler et al., 2015). Insulinlike growth factor 1 , but not 2 , is sensitive to the $\mathrm{SH}$ background, decreasing about 1.6-fold upon OVX. Interestingly the binding protein of IGF2 binding protein-like 1 (Igf2bpl1) is nearly 4 -fold increased in the male's CPs compared to female's (Table 10).

Cytokines are an interesting group of modulators of neurogenesis synthesized in the CPs' stroma and epithelia (Schwerk et al., 2015 ). These include several interleukins such as IL- $1 \alpha$, IL-1 $\beta$, IL5, IL-6, IL-7, IL-8, IL-9 and IL-15 (Borsini et al., 2015; GómezNicola et al., 2011; Larsen and Grattan, 2012; Mehler et al., 1993; Michaelson et al., 1996; Nyberg and Hallberg, 2013; Rozental et al., 1995). IL-1 $\beta$, IL-9, IL-11 and IL-15 transcripts are particularly abundant species in CPs. While IL-1 $\beta$ was significantly upregulated in males in comparison to females, the other interleukins did not show any significant expression differences according to the SH background. Other less abundant interleukins, on the other hand, seem to be modulated by SH. IL- $1 \alpha$ and IL-17C are upregulated in the CPs of OVX compared to controls, and IL17C is also up-regulated in males $v s$ females. However, IL-7 and IL-9 expression were both reduced in the CPs of adult rats following OVX, and also in sham males in comparison to females. IL- $1 \alpha$, is known to regulate neurogenesis in rat fetal mesenphalic neural precursor cells. IL-7 and IL-9 have been associated with differentiation of hippocampal neuroblasts into neurons during development and with increased neuronal survival (Mehler et al., 1993; Michaelson et al., 1996; Rozental et al., 1995). IL-17C an isoform of ILC-17A, enhances neurite outgrowth, and may have a role in the neuronal plasticity associated with inflammation (Chisholm et al., 2012).

Based on microarray data (Marques et al., 2011; Quintela et al., 2013) the CPs also express two transcripts encoding two classical pituitary hormones with relevant roles in neurogenesis; growth hormone and prolactin (Aberg, 2010; Larsen and Grattan, 2012). Both hormones induce neuronal progenitor proliferation, and promote neural stem cell migration, but only prolactin has proliferative effects on glial progenitors (Pathipati et al., 2011). Prolactin induces neurogenesis in the subventricular zone during pregnancy and is responsible for the establishment of maternal behavior (Larsen and Grattan, 2010; Pathipati et al., 2011; Shingo et al., 2003). Besides, it also stimulates neurogenesis at the hippocampus and impairs stress and anxiety behaviors after pregnancy (Torner et al., 2009; Walker et al., 2012). Gene expression of growth hormone or prolactin in the CPs has not been described so far, in spite of the presence of the proteins in the CPs' epithelia and in the CSF (Table 3). Up to recently this was thought to be a result of receptor mediated uptake of these hormones by their cognate receptors which are highly expressed at the CPs' epithelia. Recent findings suggest that other possible sources of prolactin may exist in the $\mathrm{CSF}$, as receptor mediated uptake alone is unlikely to justify prolactin levels in the CSF (Brown et al., 2016). Based on the basal levels of expression of prolactin and growth hormone in the rat female CPs and in mouse CPs (Marques et al., 2011), the CPs may be a likely source of both hormones. Ovariectomy reduced prolactin expression, and prolactin transcripts are more abundant in the female' CPs than in males' what resembles the well-known up-regulatory effect of oestrogen's over PRL expression seen in the pituitary gland (Freeman et al., 2000).

The Wingless/frizzled pathway was associated with the formation, maintenance, proliferation and migration of adult neural stem cells (Malaterre et al., 2007) and is represented in the adult CPs of rats by wingless-type MMTV integration site family, member 1, 4, $5 a$ and b, 7 and 9 and frizzled homolog 1, 2, 3, 6, 7, 8, and by frizzled-related protein and secreted frizzled-related protein. Wingless-type MMTV integration site family, member 4 expression increases following male gonadectomy, and wingless-type 4 and secreted frizzled-related protein are down-regulated in males compared to females' CPs.

Other genes associated with embryonic cell differentiation, dopamine beta-hydroxilase, GATA binding protein 4, glial-derived neurotrophic factor receptor alpha 1 and Homeo box A2, are known to regulate human embryonic stem cell renewal and differentiation and vascular remodelling (Fessner et al., 2014) and are down-regulated in males compared to females. Also, the genes associated with the visual cycle/retinoate biosynthesis retinol binding protein 1 and retinol dehydrogenase are seminal elements of the retinoic acid metabolism which is also fundamental for stem cell differentiation and frequently used to promote neural differentiation of pluripotent cells into neural cells (Okada et al., 2004). The down-regulation of retinol dehydrogenase 5 and 10 in male rat CPs compared to females' suggest that SHs may modulate the production of retinaldehyde from retinol in CPs (Yamamoto et al., 1996), which may be necessary for the development of the CNS. Retinol binding protein 1 is also decreased upon OVX and in males compared to females which may affect the transport of CPs-borne retinoic acid to the neurogenic niches of the brain.

In addition, the HIPPO signalling pathway that plays a key role in tissue homeostasis and organ size control by regulating tissuespecific stem cells, tissue repair and regeneration (Mo et al., 2014) is also downregulated in males vs females as shown by the diminished expression of InaD-Like2 (Drosophila), protein phosphatase $1 \mathrm{~J}$ and stratifin (Table 10).

Altogether, several sex differences are present in homeostatic mechanisms that may be of relevance for development and/or tissue regeneration. It is important to further evaluate whether these changes in gene expression do result in alterations in the protein levels to a point that influence specific metabolic processes and justify sex differences in physiological and/or pathological conditions.

\subsection{The CPs as a circadian oscillator}

Most physiological processes in mammals are influenced by circadian rhythms. These rhythms, have an endogenous periodicity of approximately $24 \mathrm{~h}$ and are driven by a master clock within the hypothalamic suprachiasmatic nuclei that synchronizes numerous subsidiary oscillators in extra-suprachiasmatic nuclei and peripheral tissues (Reppert and Weaver, 2001; Yamamoto et al., 2004). The suprachiasmatic nuclei is not the only structure in the brain displaying daily oscillations. Olfactory bulb, amygdala, lateral habenula, cerebellum, a variety of nuclei in the thalamus and hypothalamus, and the CPs (Fig. 2), contain the molecular machinery necessary for the generation of circadian rhythms (Albrecht, 2012; Guilding and Piggins, 2007; Quintela et al., 2015b). At the molecular level, circadian rhythms in central and in peripheral oscillators are cell-autonomous and widely described as a network of interlocking transcriptional/translational feedback loops involving a family of clock genes and their protein products (Ko and Takahashi, 2006). At the core of this clock network are the transcriptional activators, circadian locomoter output cycles protein kaput (CLOCK) and brain and muscle Arnt-like protein (BMAL; isoforms 1 and 2), associated as heterodimers, that bind to enhancer box sequences in the promoters of period 1 and period 2 (Per1 and Per2) and cryptochrome 1 and cryptochrome 2 (Cry1 and Cry2) genes, whose proteins, in turn, form multimeric complexes 
Table 11

Genes expressed in the choroid plexuses associated with circadian rhythm.

\begin{tabular}{|c|c|c|c|c|c|c|}
\hline $\begin{array}{l}\text { Gene } \\
\text { symbol }\end{array}$ & Gene name & $\begin{array}{l}\text { Female } \\
\text { sham }\end{array}$ & $\begin{array}{l}\text { OVX vs } \\
\text { Sham }\end{array}$ & $\begin{array}{l}\text { Male } \\
\text { sham }\end{array}$ & $\begin{array}{l}\text { OOX vs } \\
\text { Sham }\end{array}$ & $\begin{array}{l}\text { Male vs } \\
\text { Female }\end{array}$ \\
\hline Arntl & Aryl hydrocarbon receptor nuclear translocator-like & & & & & \\
\hline Ciart & Circadian associated repressor of transcription & & & & & \\
\hline Clock & Clock & & & & & \\
\hline Cry1 & Cryptochrome 1 & & & & & \\
\hline Cry2 & Cryptochrome 2 & & & & & \\
\hline Dbp & D site of albumin promoter (albumin D-box) binding protein & & & & & \\
\hline Per1 & Period homolog 1 (Drosophila) & & & & & \\
\hline Per2 & Period homolog 2 (Drosophila) & & & & & \\
\hline Per3 & Period homolog 3 (Drosophila) & & & & & \\
\hline
\end{tabular}

OOX - orchidectyomized male rats; OVX - ovariectomized female rats

Basal expression

$>12$

$>8$

$>4$

$<3,99$
Fold change up-regulation

$>1,5$

$>2$

$>3$
Fold change down-regulation

$>1,5$

$>2$

$>3$ that translocate into the nucleus to interact with CLOCK and BMAL, inhibiting their own transcription (Ko and Takahashi, 2006).

The most robust rhythms, beyond those observed in the suprachiasmatic nuclei, are found in the olfactory bulb and tissues that have neuroendocrine functions, such as the arcuate nucleus, the paraventricular nucleus and the pituitary gland (Albrecht, 2012). In addition, several studies demonstrated a number of differences that exist between brain tissues, including the robustness and phase of the oscillations (Abe et al., 2002). The absence or attenuated oscillations in some brain regions may allow for strong phase control by the suprachiasmatic nuclei. On the other hand, more robust oscillations may provide increased liability and a wider range of phase relationships between the suprachiasmatic nuclei and the target tissue. The suprachiasmatic nuclei is thus believed to communicate with its targets in the brain via a combination of neuronal and humoral mechanisms (Urlep and Rozman, 2013). However, it is not known if the CPs interact with the suprachiasmatic nuclei or even if the choroidal clock is under the influence of the brain's biological clock located in the suprachiasmatic nuclei. Thus, there is a clear need for further research to understand the degree of CP's autonomy and possible signals/circuits from the suprachiasmatic nuclei that could synchronize the CPs, or vice versa, since the circuits are critical for regulating physiology and behavior (Albrecht, 2012).

We have recently shown that the CPs expresses all canonical clock genes Bmal1, Clock, Cry1, Cry2, Per1 and Per2 as well as their cognate proteins (Quintela et al., 2015a). Interestingly, the expression of some of the clock genes in rat CPs exhibited circadian variations that differ between sexes. Bmal1, Cry2, Per1 and Per2 are rhythmically expressed in female rat CPs. In addition, Cry2 and Per2 also varied along the day in CPs of male rats. In contrast, Bmal1 and Per1 do not show a significant circadian variation in male rat CPs and Clock was found to be constitutively expressed in the CPs of both female and male rats (Quintela et al., 2015b). Thus, the expression of canonical clock genes put the CPs forward as a likely extra-suprachiasmatic nuclei clock. However, the functional significance of this clock machinery is still unknown.

Data retrieved from the microarray study documented the differential expression of some clock genes between males and females (Quintela et al., 2016) and as a result of gonadectomy in both sexes. For example, Bmal 1 is down-regulated, while others are up-regulated in the CPs of males compared to the CPs of females (Per2 and Per3) (Table 11). Comparison of gene expression levels between gonadectomized and sham animals showed Per2 up-regulation and Bmal1 down-regulation in OVX. Contrarily, in OOX Per2 was down-regulated (2.5-fold) and Bmal1 up-regulated (Table 11).

Circadian associated repressor of transcription (Ciart) also known as Chrono (Anafi et al., 2014) represses the transcriptional activator activity of the CLOCK/BMAL heterodimer. This is another recently identified key element of the circadian oscillator, that is also expressed by the CPs' cells and alike Per 2, and Per 3 is upregulated in males in comparison to females (Ciart, 8.4-fold). In addition, D site of albumin promoter (albumin D-box) binding protein (Dbp) is also a transcriptional activator that modulates important clock output genes (Yamaguchi et al., 2000). Dbp is increased in OVX and in males in comparison to females, whilst it is down-regulated in OOX. The differential expression of fundamental genes responsible for setting the circadian rhythmicity between males and females suggest that SHs are key regulators of the CPs rhythmicity. It is therefore clear that sex hormones regulate not only genes in the suprachiasmatic nuclei (reviewed in Mong et al., 2011)(Nakamura et al., 2005, 2010) but also in the CPs. Taken together, these observations suggest that the CPs may act as an extra-suprachiasmatic nuclei site of estrogen action, possibly functioning as an indirect route that can then modulate circadian rhythmicity. Future studies addressing the circadian clock-coordinated detoxification system of the CPs will be relevant for understanding the pharmacokinetics of drugs along the day, and improve drug efficacy and safety via the coordination of time of medication with the biological rhythms.

\section{Conclusions}

High throughput techniques such as cDNA microarrays and RNA sequencing have unveiled the transcriptome of the CPs in several experimental setups, from the early mammalian developmental stages until adulthood, in response to inflammatory stimulus, throughout aging, SH decline and between sexes. The available data reinforces the importance of the CPs in CSF production, immune surveillance, neurogenesis and brain repair, and brain detoxification metabolism. Other novel CPs functions, including chemical sensing through the olfactory and taste transductions 
pathways, have emerged from these studies, and were recently confirmed by physiological experiments. The relevance of the CPs in the establishment of circadian rhythms and its contribution to neurogenesis has also received paramount support from these studies.

The large number of CPs' genes essential to its biological functions, that are differently expressed between sexes and by the $\mathrm{SH}$ background, bring forward the relevance of SH for all known CPs functions, with particular emphasis for neurogenesis and circadian rhythm pathways (Fig. 2). It is of major interest to assess if these differences in gene expression do translate into protein expression and modulate functional outcomes between sexes, as expected from these data. Since the CPs used in these studies included the connective tissue underneath, it is also important to deploy studies that enable distinguishing between the source of many of these transcripts and encoded peptides; whether these are expressed and released from mesenchymal cells within the CP stroma or from the CPs' epithelial cells. Moreover, considering that some of the gene expression differences may arise from mesenchymal cells, another question arising from these observations is how sex hormone-driven alterations in the expression of these genes affect the cross-talk between the CPs' stroma and the CPs' epithelial cells.

Functional differences between male and female CPs are expected to impact on health and disease and may explain some of the differences seen in the onset and progression of neuronal diseases between sexes.

\section{Acknowledgements}

This work was supported by: the Portuguese Foundation for Science and Technology (FCT, Portugal - http://www.fct.pt) project grants (PTDC/SAU-NEU/114800/2009); and by FEDER funds through the POCI - COMPETE 2020 - Operational Programme Competitiveness and Internationalisation in Axis I - Strengthening research, technological development and innovation (Project No. 007491 ) and National Funds by FCT - Foundation for Science and Technology (Project UID/Multi/00709). Joana Tomás was supported by a grant from CENTRO-07-ST24-FEDER-002015. Telma Quintela is a recipient of a FCT fellowship (SFRH/BPD/70781/2010).

The work at ICVS/3B's has the support of Portuguese North Regional Operational Program (ON.2 - O Novo Norte) under the National Strategic Reference Framework (QREN), through the European Regional Development Fund (FEDER). Fernanda Marques is a recipient of a FCT Investigator award (IF/00231/2013) of the Fundação para a Ciência e Tecnologia (FCT, Portugal).

\section{References}

Abe, M., Herzog, E.D., Yamazaki, S., Straume, M., Tei, H., Sakaki, Y., Menaker, M., Block, G.D., 2002. Circadian rhythms in isolated brain regions. J. Neurosci. 22, $350-356$.

Aberg, D., 2010. Role of the growth hormone/insulin-like growth factor 1 axis in neurogenesis. Endocr. Dev. 17, 63-76. http://dx.doi.org/10.1159/000262529.

Albrecht, U., 2012. Circadian rhythms and sleep - the metabolic connection Pflügers Arch. Eur. J. Physiol. 463, 23-30. http://dx.doi.org/10.1007/s00424011-0986-6.

Alfonso-Loeches, S., Pascual, M., Guerri, C., 2013. Gender differences in alcoholinduced neurotoxicity and brain damage. Toxicology 311, 27-34. http://dx.doi. org/10.1016/j.tox.2013.03.001

Altemus, M., Jacobson, K.R., Debellis, M., Kling, M., Pigott, T., Murphy, D.L., Gold, P. W., 1999. Normal CSF oxytocin and NPY levels in OCD. Biol. Psychiatry. http:// dx.doi.org/10.1016/S0006-3223(98)00263-7.

Alves, C.H., Gonçalves, I., Socorro, S., Baltazar, G., Quintela, T., Santos, C.R.A., 2009. Androgen receptor is expressed in murine choroid plexus and downregulated by 5 alpha-dihydrotestosterone in male and female mice. J. Mol. Neurosci. 38 41-49. http://dx.doi.org/10.1007/s12031-008-9157-4.

Alvira-Botero, X., Carro, E.M., 2010. Clearance of amyloid- $\beta$ peptide across the choroid plexus in Alzheimer's disease. Curr. Aging Sci. 3, 219-229.

Anafi, R.C., Lee, Y., Sato, T.K., Venkataraman, A., Ramanathan, C., Kavakli, I.H., Hughes, M.E., Baggs, J.E., Growe, J., Liu, A.C., Kim, J., Hogenesch, J.B., Schibler, U.,
2014. Machine learning helps identify CHRONO as a circadian clock component. PLoS Biol. 12. http://dx.doi.org/10.1371/journal.pbio.1001840.

Armstead, W.M., Mirro, R., Thelin, O.P., Shibata, M., Zuckerman, S.L., Shanklin, D.R. Busija, D.W., Leffler, C.W., 1992. Polyethylene glycol superoxide dismutase and catalase attenuate increased blood-brain barrier permeability after ischemia in piglets. Stroke 23, 755-762

Badaut, J., 2010. Aquaglyceroporin 9 in brain pathologies. Neuroscience 168, 1047 1057. http://dx.doi.org/10.1016/j.neuroscience.2009.10.030.

Baruch, K., Deczkowska, a., David, E., Castellano, J.M., Miller, O., Kertser, a. Berkutzki, T., Barnett-Itzhaki, Z., Bezalel, D., Wyss-Coray, T., Amit, I., Schwartz, M., 2014. Aging-induced type I interferon response at the choroid plexus negatively affects brain function. Science (80-) 89. http://dx.doi.org/ 10.1126/science.1252945. science.1252945-..

Baruch, K., Kertser, A., Porat, Z., Schwartz, M., 2015. Cerebral nitric oxide represses choroid plexus NFKB-dependent gateway activity for leukocyte trafficking. EMBO J. 34, 1816-1828, http://dx.doi.org/10.15252/embj.201591468.

Baruch, K., Ron-Harel, N., Gal, H., Deczkowska, A., Shifrut, E., Ndifon, W., MirlasNeisberg, N., Cardon, M., Vaknin, I., Cahalon, L., Berkutzki, T., Mattson, M.P. Gomez-Pinilla, F., Friedman, N., Schwartz, M., 2013. CNS-specific immunity at the choroid plexus shifts toward destructive Th2 inflammation in brain aging Proc. Natl. Acad. Sci. U.S.A. 110, 2264-2269. http://dx.doi.org/10.1073/ pnas.1211270110.

Baruch, K., Schwartz, M., 2013. CNS-specific T cells shape brain function via the choroid plexus. Brain Behav. Immun. 34, 11-16. http://dx.doi.org/10.1016/j. bbi.2013.04.002.

Baulieu, E.E., 1998. Neurosteroids: a novel function of the brain Psychoneuroendocrinology 23, 963-987. http://dx.doi.org/10.1016/s0306 4530(98)00071-7.

Boekhoff, I., Touhara, K., Danner, S., Inglese, J., Lohse, M.J., Breer, H., Lefkowitz, R.J., 1997. Phosducin, potential role in modulation of olfactory signaling. J. Biol. Chem. 272, 4606-4612. http://dx.doi.org/10.1074/jbc.272.7.4606.

Borsini, A., Zunszain, P.A., Thuret, S., Pariante, C.M., 2015. The role of inflammatory cytokines as key modulators of neurogenesis. Trends Neurosci. 38, 145-157. http://dx.doi.org/10.1016/j.tins.2014.12.006.

Bourque, M., Liu, B., Dluzen, D.E., Di Paolo, T., 2011. Sex differences in methamphetamine toxicity in mice: effect on brain dopamine signaling pathways. Psychoneuroendocrinology 36, 955-969. http://dx.doi.org/10.1016 j.psyneuen.2010.12.007

Braun, T., Voland, P., Kunz, L., Prinz, C., Gratzl, M., 2007. Enterochromaffin cells of the human gut: sensors for spices and odorants. Gastroenterology 132, 18901901. http://dx.doi.org/10.1053/j.gastro.2007.02.036.

Bridges, R.S., 2015. Neuroendocrine regulation of maternal behavior. Front Neuroendocrinol. 36, 178-196. http://dx.doi.org/10.1016/j.yfrne.2014.11.007.

Brinker, T., Stopa, E., Morrison, J., Klinge, P., 2014. A new look at cerebrospinal fluid circulation. Fluids Barr. CNS 11, 10. http://dx.doi.org/10.1186/2045-8118-11-10.

Brinton, R.D., Thompson, R.F., Foy, M.R., Baudry, M., Wang, J., Finch, C.E., Morgan, T. E., Pike, C.J., Mack, W.J., Stanczyk, F.Z., Nilsen, J., 2008. Progesterone receptors: form and function in brain. Front. Neuroendocrinol. 29, 313-339. http://dx.doi. org/10.1016/j.yfrne.2008.02.001.

Brown, R.S.E., Wyatt, A.K., Herbison, R.E., Knowles, P.J., Ladyman, S.R., Binart, N., Banks, W.A., Grattan, D.R., 2016. Prolactin transport into mouse brain is independent of prolactin receptor. FASEB J. 30, 1002-1010. http://dx.doi.org/ 10.1096/fj.15-276519.

Chandrashekar, J., Hoon, M.A., Ryba, N.J.P., Zuker, C.S., 2006. The receptors and cells for mammalian taste. Nature 444, 288-294. http://dx.doi.org/ 10.1038/nature05401.

Chisholm, S.P., Cervi, A.L., Nagpal, S., Lomax, A.E., 2012. Interleukin-17A increases neurite outgrowth from adult postganglionic sympathetic neurons. J. Neurosci. 32, 1146-1155. http://dx.doi.org/10.1523/JNEUROSCI.5343-11.2012.

Choudhuri, S., Cherrington, N.J., Li, N., Klaassen, C.D., 2003. Constitutive expression of various xenobiotic and endobiotic transporter mRNAs in the choroid plexus of rats. Drug Metab. Dispos. 31, 1337-1345. http://dx.doi.org/10.1124| dmd.31.11.1337.

Clodfelter, K.H., Holloway, M.G., Hodor, P., Park, S.-H., Ray, W.J., Waxman, D.J., 2006 Sex-dependent liver gene expression is extensive and largely dependent upon signal transducer and activator of transcription 5b (STAT5b): STAT5bdependent activation of male genes and repression of female genes revealed by microarray analysis. Mol. Endocrinol. 20, 1333-1351. http://dx.doi.org/ 10.1210/me.2005-0489.

Coisne, C., Engelhardt, B., 2011. Tight junctions in brain barriers during central nervous system inflammation. Antioxid. Redox Signal. 15, 1285-1303. http:/ dx.doi.org/10.1089/ars.2011.3929.

Cosimo Melcangi, R., Garcia-Segura, L.M., 2010. Sex-specific therapeutic strategies based on neuroactive steroids: in search for innovative tools for neuroprotection. Horm. Behav. 57, 2-11. http://dx.doi.org/10.1016/j. yhbeh.2009.06.001. S0018-506X(09)00133-0 [pii].

Damkier, H.H., Brown, P.D., Praetorius, J., 2013. Cerebrospinal fluid secretion by the choroid plexus. Physiol. Rev. 93, 1847-1892. http://dx.doi.org 10.1152/physrev.00004.2013.

Datta, S., Hurley, R.J., Naulty, J.S., Stern, P., Lambert, D.H., Concepcion, M. Tulchinsky, D., Weiss, J.B., Ostheimer, G.W., 1986. Plasma and cerebrospinal fluid progesterone concentrations in pregnant and nonpregnant women. Anesth. Analg. 65, 950-954.

Deutsch, E.R., Espinoza, T.R., Atif, F., Woodall, E., Kaylor, J., Wright, D.W., 2013. Progesterone's role in neuroprotection, a review of the evidence. Brain Res. 1530, 82-105. http://dx.doi.org/10.1016/j.brainres.2013.07.014. 
Dhir, R.N., Dworakowski, W., Thangavel, C., Shapiro, B.H., 2006. Sexually dimorphic regulation of hepatic isoforms of human cytochrome $\mathrm{P} 450$ by growth hormone. J. Pharmacol. Exp. Ther. 316, 87-94. http://dx.doi.org/10.1124/jpet.105.093773. resulted.

Di Lorenzo, P.M., Monroe, S., 1990. Taste responses in the parabrachial pons of ovariectomized rats. Brain Res. Bull. 25, 741-748. http://dx.doi.org/10.1016/ 0361-9230(89)90151-2.

Direito, I., Madeira, A., Brito, M.A., Soveral, G., 2016. Aquaporin-5: from structure to function and dysfunction in cancer. Cell. Mol. Life Sci. http://dx.doi.org/10.1007/ s00018-016-2142-0.

Doty, R.L., Cameron, E.L., 2009. Sex differences and reproductive hormone influences on human odor perception. Physiol. Behav. 97, 213-228. http://dx. doi.org/10.1016/j.physbeh.2009.02.032.

Duarte, A.C., Hrynchak, M.V., Gonçalves, I., Quintela, T., Santos, C.R.A., 2016. Sex hormone decline and amyloid $\beta$ synthesis, transport and clearance in the brain. J. Neuroendocrinol. http://dx.doi.org/10.1111/jne.12432.

Ek, C.J., D’Angelo, B., Lehner, C., Nathanielsz, P., Li, C., Mallard, C., 2015. Expression of tight junction proteins and transporters for xenobiotic metabolism at the blood-CSF barrier during development in the nonhuman primate ( $P$. hamadryas). Reprod. Toxicol. 56, 32-44. http://dx.doi.org/10.1016/j. reprotox.2015.06.047.

Ek, C.J., Dziegielewska, K.M., Habgood, M.D., Saunders, N.R., 2012. Barriers in the developing brain and neurotoxicology. Neurotoxicology 33, 586-604. http://dx. doi.org/10.1016/j.neuro.2011.12.009.

Ek, C.J., Wong, A., Liddelow, S.a., Johansson, P.a., Dziegielewska, K.M., Saunders, N.R. 2010. Efflux mechanisms at the developing brain barriers: ABC-transporters in the fetal and postnatal rat. Toxicol. Lett. 197, 51-59. http://dx.doi.org/10.1016 j.toxlet.2010.04.025.

Engler-Chiurazzi, E.B., Brown, C.M., Povroznik, J.M., Simpkins, J.W., 2016. Estrogens as neuroprotectants: estrogenic actions in the context of cognitive aging and brain injury. Prog. Neurobiol. http://dx.doi.org/10.1016/j. pneurobio.2015.12.008.

Faas, M.M., Melgert, B.N., de Vos, P., 2010. A brief review on how pregnancy and sex hormones interfere with taste and food intake. Chemosens. Percept. 3, 51-56. http://dx.doi.org/10.1007/s12078-009-9061-5.

Falcao, A.M., Marques, F., Novais, A., Sousa, N., Palha, J.A., Sousa, J.C., 2012. The path from the choroid plexus to the subventricular zone: go with the flow! Front. Cell. Neurosci. 6, 34. http://dx.doi.org/10.3389/fncel.2012.00034.

Farinetti, A., Tomasi, S., Foglio, B., Ferraris, A., Ponti, G., Gotti, S., Peretto, P., Panzica, G.C., 2015. Testosterone and estradiol differentially affect cell proliferation in the subventricular zone of young adult gonadectomized male and female rats. Neuroscience 286, 162-170. http://dx.doi.org/10.1016/j. neuroscience.2014.11.050.

Fessner, A., Esser, J.S., Bluhm, F., Grundmann, S., Zhou, Q., Patterson, C., Bode, C. Moser, M., 2014. The transcription factor HoxB5 stimulates vascular remodelling in a cytokine-dependent manner. Cardiovasc. Res. 101, 247-255 http://dx.doi.org/10.1093/cvr/cvt244.

Freeman, M.E., Kanyicska, B., Lerant, A., Nagy, G., 2000. Prolactin: structure, function, and regulation of secretion. Physiol. Rev. 80, 1523-1631.

Galea, L.A.M., Wainwright, S.R., Roes, M.M., Duarte-Guterman, P., Chow, C., Hamson, D.K., 2013. Sex, hormones and neurogenesis in the hippocampus: hormonal modulation of neurogenesis and potential functional implications. J. Neuroendocrinol. 25, 1039-1061. http://dx.doi.org/10.1111/jne.12070.

Ghersi-Egea, JF, Leninger-Muller, B, Suleman, G. Siest, G Minn, A 1994 Localization of drug-metabolizing enzyme activities to blood-brain interfaces and circumventricular organs. J. Neurochem. 62, 1089-1096.

Ghersi-Egea, J.-F., Strazielle, N., Murat, A., Jouvet, A., Buénerd, A., Belin, M.-F., 2006 Brain protection at the blood-cerebrospinal fluid interface involves a glutathione-dependent metabolic barrier mechanism. J. Cereb. Blood Flow Metab. 26, 1165-1175. http://dx.doi.org/10.1038/sj.jcbfm.9600267.

Ghersi-Egea, J.-F.F., Monkkonen, K.S., Schmitt, C., Honnorat, J., Fevre-Montange, M., Strazielle, N., 2009. Blood-brain interfaces and cerebral drug bioavailability. Rev. Neurol. 165, 1029-1038. http://dx.doi.org/10.1016/j.neurol.2009.09.011.

Gillies, G.E., Pienaar, I.S., Vohra, S., Qamhawi, Z., 2014. Sex differences in Parkinson's disease. Front. Neuroendocrinol. 35, 370-384. http://dx.doi.org/10.1016/j. yfrne.2014.02.002.

Gómez-Nicola, D., Valle-Argos, B., Pallas-Bazarra, N., Nieto-Sampedro, M., 2011 Interleukin-15 regulates proliferation and self-renewal of adult neural stem cells. Mol. Biol. Cell 22, 1960-1970. http://dx.doi.org/10.1091/mbc.E11-01 0053.

Gonçalves, I., Hubbard, P.C., Tomás, J., Quintela, T., Tavares, G., Caria, S., Barreiros, D. Santos, R.A.C., 2016. "Smelling" the cerebrospinal fluid: olfactory signaling molecules are expressed in and mediate chemosensory signaling from the choroid plexus. FEBS J. http://dx.doi.org/10.1111/febs.13700.

González-Marrero, I., Giménez-Llort, L., Johanson, C.E., Carmona-Calero, E.M. Castañeyra-Ruiz, L., Brito-Armas, J.M., Castañeyra-Perdomo, A., CastroFuentes, R., 2015. Choroid plexus dysfunction impairs beta-amyloid clearance in a triple transgenic mouse model of Alzheimer's disease. Front. Cell. Neurosci. 9. 17. http://dx doi.org/10.3389/fncel.2015.00017.

Griffin, C.A., Kafadar, K.A., Pavlath, G.K., 2009. MOR23 promotes muscle regeneration and regulates cell adhesion and migration. Dev. Cell 17, 649661. http://dx.doi.org/10.1016/j.devcel.2009.09.004.

Grison, A., Zucchelli, S., Urzi, A., Zamparo, I., Lazarevic, D., Pascarella, G., Roncaglia, P., Giorgetti, A., Garcia-Esparcia, P., Vlachouli, C., Simone, R., Persichetti, F. Forrest, A.R., Hayashizaki, Y., Carloni, P., Ferrer, I., Lodovichi, C., Plessy, C. Carninci, P., Gustincich, S., 2014. Mesencephalic dopaminergic neurons express a repertoire of olfactory receptors and respond to odorant-like molecules. BMC Genom. 15, 729. http://dx.doi.org/10.1186/1471-2164-15-729.

Guilding, C., Piggins, H.D., 2007. Challenging the omnipotence of the suprachiasmatic timekeeper: are circadian oscillators present throughout the mammalian brain? Eur. J. Neurosci. 25, 3195-3216. http://dx.doi.org/10.1111/ j.1460-9568.2007.05581.x.

Hanamsagar, R., Bilbo, S.D., 2016. Sex differences in neurodevelopmental and neurodegenerative disorders: focus on microglial function and neuroinflammation during development. J. Steroid Biochem. Mol. Biol. 160, 127-133. http://dx.doi.org/10.1016/j.jsbmb.2015.09.039.

Hong-Goka, B.C., Chang, F.-L.F., 2004. Estrogen receptors $\alpha$ and $\beta$ in choroid plexus epithelial cells in Alzheimer's disease. Neurosci. Lett. http://dx.doi.org/10.1016/ j.neulet.2004.01.075.

Imbrici, P., Altamura, C., Pessia, M., Mantegazza, R., Desaphy, J.-F., Camerino, D.C., 2015. ClC-1 chloride channels: state-of-the-art research and future challenges. Front. Cell. Neurosci. 9, 156. http://dx.doi.org/10.3389/fncel.2015.00156.

Iwamoto, T., Ouchi, Y., 2014. Emerging evidence of insulin-like growth factor 2 as a memory enhancer: a unique animal model of cognitive dysfunction with impaired adult neurogenesis. Rev. Neurosci. 25, 559-574. http://dx.doi.org/ 10.1515/revneuro-2014-0010.

Johanson, C., Stopa, E., Baird, A., Sharma, H., 2011. Traumatic brain injury and recovery mechanisms: peptide modulation of periventricular neurogenic regions by the choroid plexus-CSF nexus. J. Neural Transm. 118, 115-133. http://dx.doi.org/10.1007/s00702-010-0498-0.

Johansson, P.A., 2014. The choroid plexuses and their impact on developmental neurogenesis. Front. Neurosci. 8, 340. http://dx.doi.org/10.3389/ fnins.2014.00340.

Keller, A., Zhuang, H., Chi, Q., Vosshall, L.B., Matsunami, H., 2007. Genetic variation in a human odorant receptor alters odour perception. Nature 449, 468-472. http://dx.doi.org/10.1038/nature06162.

Kepp, K.P., 2016. Alzheimer's disease due to loss of function: a new synthesis of the available data. Prog. Neurobiol. 143, 36-60. http://dx.doi.org/10.1016/j. pneurobio.2016.06.004.

Ko, C.H., Takahashi, J.S., 2006. Molecular components of the mammalian circadian clock. Hum. Mol. Genet. 15, 271-277. http://dx.doi.org/10.1093/hmg/ddl207.

Koshibu, K., Levitt, P., 2005. Sex differences in expression of transforming growth factor- $\alpha$ and epidermal growth factor receptor mRNA in waved- 1 and C57Bl6 mice. Neuroscience 134, 877-887. http://dx.doi.org/10.1016/j. neuroscience.2005.03.016.

Kratzer, I., Liddelow, S.A., Saunders, N.R., Dziegielewska, K.M., Strazielle, N., GhersiEgea, J.-F.F., 2013. Developmental changes in the transcriptome of the rat choroid plexus in relation to neuroprotection. Fluids Barr. CNS 10, 25. http://dx. doi.org/10.1186/2045-8118-10-25.

Kratzer, I., Vasiljevic, A., Rey, C., Fevre-Montange, M., Saunders, N., Strazielle, N. Ghersi-Egea, J.-F., 2012. Complexity and developmental changes in the expression pattern of claudins at the blood-CSF barrier. Histochem. Cell Biol. 138, 861-879. http://dx.doi.org/10.1007/s00418-012-1001-9.

Kunis, G., Baruch, K., Rosenzweig, N., Kertser, A., Miller, O., Berkutzki, T., Schwartz, M., 2013. IFN- $\gamma$-dependent activation of the brain's choroid plexus for CNS immune surveillance and repair. Brain 136, 3427-3440. http://dx.doi.org/ 10.1093 /brain/awt259.

Larsen, C.M., Grattan, D.R., 2012. Prolactin, neurogenesis, and maternal behaviors. Brain Behav. Immun. 26, 201-209. http://dx.doi.org/10.1016/j.bbi.2011.07.233.

Larsen, C.M. Grattan, D.R. 2010. Prolactin-induced mitogenesis in the subventricular zone of the maternal brain during early pregnancy is essential for normal postpartum behavioral responses in the mother. Endocrinology 151, 3805-3814. http://dx.doi.org/10.1210/en.2009-1385.

Li, R., Singh, M., 2014. Sex differences in cognitive impairment and Alzheimer's disease. Front. Neuroendocrinol. 35, 385-403. http://dx.doi.org/10.1016/j. yfrne.2014.01.002

Lun, M.P., Monuki, E.S., Lehtinen, M.K., 2015. Development and functions of the choroid plexus-cerebrospinal fluid system. Nat. Rev. Neurosci. 16, 445-457. http://dx.doi.org/10.1038/nrn3921.

Macković, M., Zimolo, Z., Burckhardt, G., Sabolić, I., 1986. Isolation of renal brushborder membrane vesicles by a low-speed centrifugation; effect of sex hormones on $\mathrm{Na}^{+}-\mathrm{H}^{+}$exchange in rat and mouse kidney. Biochim. Biophys. Acta $862,141-152$.

Mahmoud, R., Wainwright, S.R., Galea, L.A.M., 2016. Sex hormones and adult hippocampal neurogenesis: regulation, implications, and potential mechanisms. Front. Neuroendocrinol. 41, 129-152. http://dx.doi.org/10.1016/ j.yfrne.2016.03.002.

Malaterre, J., Ramsay, R.G., Mantamadiotis, T., 2007. Wnt-Frizzled signalling and the many paths to neural development and adult brain homeostasis. Front. Biosci. 12, 492-506.

Markianos, M. Koutsis, G., Evangelopoulos, M.E., Mandellos, D., Sfagos, C., 2010 Serum and cerebrospinal fluid prolactin levels in male and female patients with clinically-isolated syndrome or relapsing-remitting multiple sclerosis. J. Neuroendocrinol. 22, 503-508 http://dx.doi.org/10.1111/j.13652826.2010.01972.x.

Marques, F., Falcao, A.M., Sousa, J.C., Coppola, G., Geschwind, D., Sousa, N., CorreiaNeves, M., Palha, J.A., 2009c. Altered iron metabolism is part of the choroid plexus response to peripheral inflammation. Endocrinology 150, 2822-2828. http://dx.doi.org/10.1210/en.2008-1610.

Marques, F., Mesquita, S.D., Sousa, J.C., Coppola, G., Gao, F., Geschwind, D.H., Columba-Cabezas, S., Aloisi, F., Degn, M., Cerqueira, J.J., Sousa, N., Correia-Neves, M., Palha, J.A., 2012. Lipocalin 2 is present in the EAE brain and is modulated by 
natalizumab. Front. Cell. Neurosci. 6, 33. http://dx.doi.org/10.3389/ fncel.2012.00033.

Marques, F., Sousa, J.C., Brito, M.A., Pahnke, J., Santos, C., Correia-Neves, M., Palha, J. A., 2016. The choroid plexus in health and in disease: dialogues into and out of the brain. Neurobiol. Dis. http://dx.doi.org/10.1016/j.nbd.2016.08.011.

Marques, F., Sousa, J.C., Coppola, G., Falcao, A.M., Rodrigues, A.J., Geschwind, D.H., Sousa, N., Correia-Neves, M., Palha, J.A., 2009a. Kinetic profile of the transcriptome changes induced in the choroid plexus by peripheral inflammation. J. Cereb. Blood Flow Metab. 29, 921-932. http://dx.doi.org/ 10.1038/jcbfm.2009.15.

Marques, F., Sousa, J.C., Coppola, G., Gao, F., Puga, R., Brentani, H., Geschwind, D.H., Sousa, N., Correia-Neves, M., Palha, J.A., 2011. Transcriptome signature of the adult mouse choroid plexus. Fluids Barr. CNS 8, 10. http://dx.doi.org/10.1186/ 2045-8118-8-10.

Marques, F., Sousa, J.C., Coppola, G., Geschwind, D.H., Sousa, N., Palha, J.A., CorreiaNeves, M., 2009b. The choroid plexus response to a repeated peripheral inflammatory stimulus. BMC Neurosci. 10, 135. http://dx.doi.org/10.1186/14712202-10-135.

Martínez, S.E., Vaglenova, J., Sabrià, J., Martínez, M.C., Farrés, J., Parés, X., 2001. Distribution of alcohol dehydrogenase mRNA in the rat central nervous system. Eur. J. Biochem. 268, 5045-5056. http://dx.doi.org/10.1046/j.00142956.2001.02416.X-i2

Matsumoto, K., Chiba, Y., Fujihara, R., Kubo, H., Sakamoto, H., Ueno, M., 2015. Immunohistochemical analysis of transporters related to clearance of amyloid$\beta$ peptides through blood-cerebrospinal fluid barrier in human brain. Histochem. Cell Biol. 144, 597-611. http://dx.doi.org/10.1007/s00418-0151366-7.

Meffre, D., Delespierre, B., Gouézou, M., Leclerc, P., Vinson, G.P., Schumacher, M., Stein, D.G., Guennoun, R., 2005. The membrane-associated progesteronebinding protein 25-Dx is expressed in brain regions involved in water homeostasis and is up-regulated after traumatic brain injury. J. Neurochem. 93, 1314-1326. http://dx.doi.org/10.1111/j.1471-4159.2005.03127.x.

Meffre, D., Labombarda, F., Delespierre, B., Chastre, A., De Nicola, A.F., Stein, D.G., Schumacher, M., Guennoun, R., 2013. Distribution of membrane progesterone receptor alpha in the male mouse and rat brain and its regulation after traumatic brain injury. Neuroscience 231, 111-124. http://dx.doi.org/10.1016/j. neuroscience.2012.11.039.

Mehler, M.F., Rozental, R., Dougherty, M., Spray, D.C., Kessler, J.A., 1993. Cytokine regulation of neuronal differentiation of hippocampal progenitor cells. Nature 362, 62-65. http://dx.doi.org/10.1038/362062a0.

Melcangi, R.C., Caruso, D., Abbiati, F., Giatti, S., Calabrese, D., Piazza, F., Cavaletti, G., 2013. Neuroactive steroid levels are modified in cerebrospinal fluid and plasma of post-finasteride patients showing persistent sexual side effects and anxious/ depressive symptomatology. J. Sex. Med. 10, 2598-2603. http://dx.doi.org/ $10.1111 /$ jsm. 12269 .

Merched, A., Serot, J.M., Visvikis, S., Aguillon, D., Faure, G., Siest, G., 1998. Apolipoprotein E, transthyretin and actin in the CSF of Alzheimer's patients: relation with the senile plaques and cytoskeleton biochemistry. FEBS Lett. 425, 225-228.

Mesquita, S.D., Ferreira, A.C., Gao, F., Coppola, G., Geschwind, D.H., Sousa, J.C., Correia-Neves, M., Sousa, N., Palha, J.A., Marques, F., 2015. The choroid plexus transcriptome reveals changes in type I and II interferon responses in a mouse model of Alzheimer's disease. Brain Behav. Immun. 49, 280-292. http://dx.doi. org/10.1016/j.bbi.2015.06.008.

Michaelson, M.D., Mehler, M.F., Xu, H., Gross, R.E., Kessler, J.A., 1996. Interleukin-7 is trophic for embryonic neurons and is expressed in developing brain. Dev. Biol. 179, 251-263. http://dx.doi.org/10.1006/dbio.1996.0255.

Mo, J.-S., Park, H.W., Guan, K.-L., 2014. The Hippo signaling pathway in stem cell biology and cancer. EMBO Rep. 15, 642-656. http://dx.doi.org/10.15252/ embr.201438638.

Molnár, G., Kassai-Bazsa, Z., 1997. Gonadotropin, ACTH, prolactin, sexual steroid and cortisol levels in postmenopausal women's cerebrospinal fluid (CSF). Arch. Gerontol. Geriatr. 24, 269-280. http://dx.doi.org/10.1016/S0167-4943(96) 00764-9.

Mong, J.A., Baker, F.C., Mahoney, M.M., Paul, K.N., Schwartz, M.D., Semba, K., Silver, R., 2011. Sleep, rhythms, and the endocrine brain: influence of sex and gonadal hormones. J. Neurosci. 31, 16107-16116. http://dx.doi.org/10.1523/ JNEUROSCI.4175-11.2011.

Mugford, C., Kedderis, G., 1998. Sex-dependent metabolism of xenobiotics. Drug Metab. Rev. 30, 441-498. http://dx.doi.org/10.3109/03602539808996322.

Nakamura, T.J., Moriya, T., Inoue, S., Shimazoe, T., Watanabe, S., Ebihara, S., Shinohara, K., 2005. Estrogen differentially regulates expression of Per1 and Per2 genes between central and peripheral clocks and between reproductive and nonreproductive tissues in female rats. J. Neurosci. Res. 82, 622-630. http:// dx.doi.org/10.1002/jnr.20677.

Nakamura, T.J., Sellix, M.T., Kudo, T., Nakao, N., Yoshimura, T., Ebihara, S., Colwell, C. S., Block, G.D., 2010. Influence of the estrous cycle on clock gene expression in reproductive tissues: effects of fluctuating ovarian steroid hormone levels. Steroids 75, 203-212. http://dx.doi.org/10.1016/j.steroids.2010.01.007.

Nieto-Estévez, V., Defterali, Ç., Vicario-Abejón, C., 2016. IGF-I: a key growth factor that regulates neurogenesis and synaptogenesis from embryonic to adult stages of the brain. Front. Neurosci. 10, 52. http://dx.doi.org/10.3389/ fnins.2016.00052.

Nyberg, F., Hallberg, M., 2013. Growth hormone and cognitive function. Nat. Rev. Endocrinol. 9, 357-365. http://dx.doi.org/10.1038/nrendo.2013.78.
O'Kusky, J., Ye, P., 2012. Neurodevelopmental effects of insulin-like growth factor signaling. Front. Neuroendocrinol. 33, 230-251. http://dx.doi.org/10.1016/j. yfrne.2012.06.002.

Okada, Y., Shimazaki, T., Sobue, G., Okano, H., 2004. Retinoic-acid-concentrationdependent acquisition of neural cell identity during in vitro differentiation of mouse embryonic stem cells. Dev. Biol. 275, 124-142. http://dx.doi.org/ 10.1016/j.ydbio.2004.07.038.

Otaki, J.M., Yamamoto, H., Firestein, S., 2004. Odorant receptor expression in the mouse cerebral cortex. J. Neurobiol. 58, 315-327. http://dx.doi.org/10.1002/ neu.10272.

Page-Wilson, G., Meece, K., White, A., Rosenbaum, M., Leibel, R.L., Smiley, R., Wardlaw, S.L., 2015. Proopiomelanocortin, agouti-related protein, and leptin in human cerebrospinal fluid: correlations with body weight and adiposity. Am. J. Physiol. Endocrinol. Metab. 309, E458-E465. http://dx.doi.org/10.1152/ ajpendo.00206.2015.

Pahnke, J., Langer, O., Krohn, M., 2014. Alzheimer's and ABC transporters - new opportunities for diagnostics and treatment. Neurobiol. Dis. 72 (Pt A), 54-60. http://dx.doi.org/10.1016/j.nbd.2014.04.001.

Palha, J.A., 2002. Transthyretin as a thyroid hormone carrier: function revisited. Clin. Chem. Lab. Med. 40, 1292-1300. http://dx.doi.org/10.1515/ CCLM.2002.223.

Pascale, C.L., Miller, M.C., Chiu, C., Boylan, M., Caralopoulos, I.N., Gonzalez, L., Johanson, C.E., Silverberg, G.D., 2011. Amyloid-beta transporter expression at the blood-CSF barrier is age-dependent. Fluids Barr. CNS 8, 21. http://dx.doi.org/ 10.1186/2045-8118-8-21.

Pastrana, E., 2013. Stem cells: the developing human brain-modeled in a dish. Nat Methods 10, 929. http://dx.doi.org/10.1038/nmeth.2674.

Pathipati, P., Gorba, T., Scheepens, A., Goffin, V., Sun, Y., Fraser, M., 2011. Growth hormone and prolactin regulate human neural stem cell regenerative activity. Neuroscience 190, 409-427. http://dx.doi.org/10.1016/j. neuroscience.2011.05.029.

Pawluski, J.L., Brummelte, S., Barha, C.K., Crozier, T.M., Galea, L.A.M., 2009. Effects of steroid hormones on neurogenesis in the hippocampus of the adult female rodent during the estrous cycle, pregnancy, lactation and aging. Front Neuroendocrinol. 30, 343-357. http://dx.doi.org/10.1016/j.yfrne.2009.03.007.

Philbert, M.A., Beiswanger, C.M., Manson, M.M., Green, J.A., Novak, R.F., Primiano, T. Reuhl, K.R., Lowndes, H.E., 1995. Glutathione S-transferases and gammaglutamyl transpeptidase in the rat nervous systems: a basis for differential susceptibility to neurotoxicants. Neurotoxicology 16, 349-362.

Pluznick, J.L., Zou, D.J., Zhang, X., Yan, Q., Rodriguez-Gil, D.J., Eisner, C., Wells, E. Greer, C.A., Wang, T., Firestein, S., Schnermann, J., Caplan, M.J., 2009. Functional expression of the olfactory signaling system in the kidney. Proc. Natl. Acad. Sci. U.S.A. 106, 2059-2064. http://dx.doi.org/10.1073/pnas.0812859106.

Quadros, P.S., Pfau, J.L., Wagner, C.K., 2007. Distribution of progesterone receptor immunoreactivity in the fetal and neonatal rat forebrain. J. Comp. Neurol. 504 42-56. http://dx.doi.org/10.1002/cne.21427.

Quintela, T., Goncalves, I., Baltazar, G., Alves, C.H., Saraiva, M.J., Santos, C.R., 2009 17beta-estradiol induces transthyretin expression in murine choroid plexus via an oestrogen receptor dependent pathway. Cell. Mol. Neurobiol. 29, 475-483. http://dx.doi.org/10.1007/s10571-008-9339-1.

Quintela, T., Gonçalves, I., Carreto, L.C., Santos, M.A.S., Marcelino, H., Patriarca, F. M., Santos, C.R.A., Goncalves, I., Carreto, L.C., Santos, M.A.S., Marcelino, H., Patriarca, F.M., Santos, C.R.A., 2013. Analysis of the effects of sex hormone background on the rat choroid plexus transcriptome by cDNA microarrays PLoS ONE 8, e60199. http://dx.doi.org/10.1371/journal.pone.0060199. PONED-12-35720 [pii].

Quintela, T., Gonçalves, I., Martinho, A., Alves, C.H., Saraiva, M.J., Rocha, P., Santos, C. R.A., 2011. Progesterone enhances transthyretin expression in the rat choroid plexus in vitro and in vivo via progesterone receptor. J. Mol. Neurosci. 44, 152158. http://dx.doi.org/10.1007/s12031-010-9398-x.

Quintela, T., Marcelino, H., Deery, M.J., Feret, R., Howard, J., Lilley, K.S., Albuquerque, T., Gonçalves, I., Duarte, A.C., Santos, C.R.A., 2016. Sex-related differences in rat choroid plexus and cerebrospinal fluid: a cDNA microarray and proteomic analysis. J. Neuroendocrinol. 28. http://dx.doi.org/10.1111/jne.12340.

Quintela, T., Marcelino, H., Gonçalves, I., Patriarca, F.M., Santos, C.R.A., 2015a. Gene expression profiling in the hippocampus of orchidectomized rats. J. Mol Neurosci. 55, 198-205. http://dx.doi.org/10.1007/s12031-014-0304-9.

Quintela, T., Sousa, C., Patriarca, F.M., Gonçalves, I., Santos, C.R.A., 2015b. Gender associated circadian oscillations of the clock genes in rat choroid plexus. Brain Struct. Funct. 220, 1251-1262. http://dx.doi.org/10.1007/s00429-014-0720-1.

Redzic, Z.B., Segal, M.B., 2004. The structure of the choroid plexus and the physiology of the choroid plexus epithelium. Adv. Drug Deliv. Rev. 56, 16951716. http://dx.doi.org/10.1016/j.addr.2004.07.005.

Reppert, S.M., Weaver, D.R., 2001. Molecular analysis of mammalian circadian rhythms. Annu. Rev. Physiol. 63, 647-676. http://dx.doi.org/10.1146/ annurev.physiol.63.1.647.

Richard, K., Hume, R., Kaptein, E., Stanley, E.L., Visser, T.J., Coughtrie, M.W., 2001. Sulfation of thyroid hormone and dopamine during human development: ontogeny of phenol sulfotransferases and arylsulfatase in liver, lung, and brain J. Clin. Endocrinol. Metab. 86, 2734-2742. http://dx.doi.org/10.1210/ jcem.86.6.7569.

Richardson, S.J., Wijayagunaratne, R.C., D'Souza, D.G., Darras, V.M., Van Herck, S.L.J., 2015. Transport of thyroid hormones via the choroid plexus into the brain: the roles of transthyretin and thyroid hormone transmembrane transporters. Front. Neurosci. 9, 1-8. http://dx.doi.org/10.3389/fnins.2015.00066. 
Rosenkranz-Weiss, P., Tomek, R.J., Mathew, J., Eghbali, M., 1994. Gender-specific differences in expression of mRNAs for functional and structural proteins in rat ventricular myocardium. J. Mol. Cell. Cardiol. 26, 261-270.

Rozental, R., Mehler, M.F., Morales, M., Andrade-Rozental, A.F., Kessler, J.A., Spray, D. C., 1995. Differentiation of hippocampal progenitor cells in vitro: tempora expression of intercellular coupling and voltage- and ligand-gated responses. Dev. Biol. 167, 350-362. http://dx.doi.org/10.1006/dbio.1995.1029.

Santos, C.R.A., Martinho, A., Quintela, T., Gonçalves, I., 2012. Neuroprotective and neuroregenerative properties of metallothioneins. IUBMB Life 64, 126-135. http://dx.doi.org/10.1002/iub.585.

Schiffer, E., van Gessel, E., Gamulin, Z., 1999. Influence of sex on cerebrospinal fluid density in adults. Br. J. Anaesth. 83, 943-944. http://dx.doi.org/10.1093/bja/ 83.6.943.

Schmid Daners, M., Knobloch, V., Soellinger, M., Boesiger, P., Seifert, B., Guzzella, L. Kurtcuoglu, V., 2012. Age-specific characteristics and coupling of cerebral arterial inflow and cerebrospinal fluid dynamics. PLoS ONE 7, e37502. http://dx. doi.org/10.1371/journal.pone.0037502.

Schmidt, F.M., Kratzsch, J., Gertz, H.-J., Tittmann, M., Jahn, I., Pietsch, U.-C., Kaisers, U.X., Thiery, J., Hegerl, U., Schönknecht, P., 2013. Cerebrospinal fluid melaninconcentrating hormone $(\mathrm{MCH})$ and hypocretin-1 (HCRT-1, orexin-A) in Alzheimer's disease. PLoS ONE 8, e63136. http://dx.doi.org/10.1371/journal. pone.0063136.

Schneeberger, E.E., Lynch, R.D., 2004. The tight junction: a multifunctional complex. Am. J. Physiol. Cell Physiol. 286, C1213-C1228. http://dx.doi.org/10.1152/ ajpcell.00558.2003.

Schulz, R., 2001. The pharmacology of phosducin. Pharmacol. Res. 43, 1-10. http:/ dx.doi.org/10.1006/phrs.2000.0757.

Schwartz, M., Baruch, K., 2014. The resolution of neuroinflammation in neurodegeneration: leukocyte recruitment via the choroid plexus. EMBO J. 33, 7-22. http://dx.doi.org/10.1002/embj.201386609.

Schwerk, C., Tenenbaum, T., Kim, K.S., Schroten, H., 2015. The choroid plexus-a multi-role player during infectious diseases of the CNS. Front. Cell. Neurosci. 9, 80. http://dx.doi.org/10.3389/fncel.2015.00080.

Serot, J.M., Christmann, D., Dubost, T., Béne, M.C., Faure, G.C., 2001. CSF-folate levels are decreased in late-onset AD patients. J. Neural Transm. 108, 93-99. http://dx doi.org/10.1007/s007020170100.

Shingo, T., Gregg, C., Enwere, E., Fujikawa, H., Hassam, R., Geary, C., Cross, J.C., Weiss, S., 2003. Pregnancy-stimulated neurogenesis in the adult female forebrain mediated by prolactin. Science 299, 117-120. http://dx.doi.org 10.1126/science.1076647.

Soldin, O.P., Chung, S.H., Mattison, D.R., 2011. Sex differences in drug disposition. J. Biomed. Biotechnol. 2011, 7-9. http://dx.doi.org/10.1155/2011/187103.

Soldin, O.P., Mattison, D.R., 2009. Sex differences in pharmacokinetics an pharmacodynamics. Clin. Pharmacokinet. 48, 143-157. http://dx.doi.org 10.2165/00003088-200948030-00001.

Sorge, R.E., Totsch, S.K., 2016. Sex differences in pain. J. Neurosci. Res. http://dx.doi. org/10.1002/jnr.23841.

Spector, R., Robert Snodgrass, S., Johanson, C.E., 2015. A balanced view of the cerebrospinal fluid composition and functions: focus on adult humans. Exp. Neurol. 273, 57-68. http://dx.doi.org/10.1016/j.expneurol.2015.07.027.

Strazielle, N., Ghersi-Egea, J.F., 1999. Demonstration of a coupled metabolism-efflux process at the choroid plexus as a mechanism of brain protection toward xenobiotics. J. Neurosci. 19, 6275-6289.

Strazielle, N., Khuth, S.T., Ghersi-Egea, J.F., 2004. Detoxification systems, passive and specific transport for drugs at the blood-CSF barrier in normal and pathological situations. Adv. Drug Deliv. Rev. 56, 1717-1740. http://dx.doi.org/10.1016/j. addr.2004.07.006.

Sumanasekera, W.K., Sumanasekera, G.U., Mattingly, K.A., Dougherty, S.M., Keynton, R.S., Klinge, C.M., 2007. Estradiol and dihydrotestosterone regulate endothelial cell barrier function after hypergravity-induced alterations in MAPK activity. Am. J. Physiol. Cell Physiol. 293, C566-C573. http://dx.doi.org/10.1152 ajpcell.00418.2006.
Tatar, C., Bessert, D., Tse, H., Skoff, R.P., 2013. Determinants of central nervous system adult neurogenesis are sex, hormones, mouse strain, age, and brain region. Glia 61, 192-209. http://dx.doi.org/10.1002/glia.22426.

Tejera-Alhambra, M., Alonso, B., Teijeiro, R., Ramos-Medina, R., Aristimuño, C., Valor, L., de Andrés, C., Sánchez-Ramón, S., 2012. Perforin expression by CD4+ regulatory $\mathrm{T}$ cells increases at multiple sclerosis relapse: sex differences. Int. J. Mol. Sci. 13, 6698-6710. http://dx.doi.org/10.3390/ijms13066698.

Thouvenot, E., Lafon-Cazal, M., Demettre, E., Jouin, P., Bockaert, J., Marin, P., 2006. The proteomic analysis of mouse choroid plexus secretome reveals a high protein secretion capacity of choroidal epithelial cells. Proteomics 6, 59415952. http://dx.doi.org/10.1002/pmic.200600096.

Tietz, S., Engelhardt, B., 2015. Brain barriers: crosstalk between complex tight junctions and adherens junctions. J. Cell Biol. 209, 493-506. http://dx.doi.org/ $10.1083 / \mathrm{jcb} .201412147$.

Tomás, J., Santos, C.R.A.R., Quintela, T., Gonçalves, I., 2016. Tasting the cerebrospinal fluid: another function of the choroid plexus. Neuroscience 320, 160-171. http://dx.doi.org/10.1016/j.neuroscience.2016.01.057.

Torner, L., Karg, S., Blume, A., Kandasamy, M., Kuhn, H.-G., Winkler, J., Aigner, L., Neumann, I.D., 2009. Prolactin prevents chronic stress-induced decrease of adult hippocampal neurogenesis and promotes neuronal fate. J. Neurosci. 29, 1826-1833. http://dx.doi.org/10.1523/JNEUROSCI.3178-08.2009.

Urlep, Z., Rozman, D., 2013. The interplay between circadian system, cholesterol synthesis, and steroidogenesis affects various aspects of female reproduction Front. Endocrinol. (Lausanne) 4, 111. http://dx.doi.org/10.3389/ fendo.2013.00111.

Van Itallie, C.M., Anderson, J.M., 2006. Claudins and epithelial paracellular transport tight junctions and paracellular transport. Annu. Rev. Physiol. 68, 403-429. http://dx.doi.org/10.1146/annurev.physiol.68.040104.131404.

Walker, T.L., Vukovic, J., Koudijs, M.M., Blackmore, D.G., Mackay, E.W., Sykes, A.M., Overall, R.W., Hamlin, A.S., Bartlett, P.F., 2012. Prolactin stimulates precursor cells in the adult mouse hippocampus. PLoS ONE 7, e44371. http://dx.doi.org/ 10.1371/journal.pone.0044371.

Wolburg, H., Wolburg-Buchholz, K., Liebner, S., Engelhardt, B., 2001. Claudin-1, claudin-2 and claudin-11 are present in tight junctions of choroid plexus epithelium of the mouse. Neurosci. Lett. http://dx.doi.org/10.1016/S0304-3940 (01)01927-9.

Yamaguchi, S., Mitsui, S., Yan, L., Yagita, K., Miyake, S., Okamura, H., 2000. Role of DBP in the circadian oscillatory mechanism. Mol. Cell. Biol. 20, 4773-4781.

Yamamoto, M., McCaffery, P., Dräger, U.C., 1996. Influence of the choroid plexus on cerebellar development: analysis of retinoic acid synthesis. Brain Res. Dev. Brain Res. 93, 182-190.

Yamamoto, T., Nakahata, Y., Soma, H., Akashi, M., Mamine, T., Takumi, T., 2004. Transcriptional oscillation of canonical clock genes in mouse peripheral tissues. BMC Mol. Biol. 5, 18. http://dx.doi.org/10.1186/1471-2199-5-18.

Yang, L., Li, Y., Hong, H., Chang, C.-W., Guo, L.-W., Lyn-Cook, B., Ning, L.S., Yang, B., 2012. Sex differences in the expression of drug-metabolizing and transporter genes in human liver 3. http://dx.doi.org/10.4172/2157-7609.1000119.

Yücel, F., Akdoğan, I., Güven, G., Ortuğ, G., 2002. SEM examination of the dorsal lingual papillae of pregnant rats. Ann. Anat. - Anat. Anzeiger 184, 251-255. http://dx.doi.org/10.1016/S0940-9602(02)80116-9.

Zanger, U.M., Schwab, M., 2013. Cytochrome P450 enzymes in drug metabolism: regulation of gene expression, enzyme activities, and impact of genetic variation. Pharmacol. Ther. 138, 103-141. http://dx.doi.org/10.1016/j. pharmthera.2012.12.007.

Zheng, J., Zhang, P., Li, X., Lei, S., Li, W., He, X., Zhang, J., Wang, N., Qi, C., Chen, X., Lu, H., Liu, Y., 2013. Post-stroke estradiol treatment enhances neurogenesis in the subventricular zone of rats after permanent focal cerebral ischemia. Neuroscience 231, 82-90. http://dx.doi.org/10.1016/j.neuroscience.2012. 11.042 .

Ziegler, A.N., Levison, S.W., Wood, T.L., 2015. Insulin and IGF receptor signalling in neural-stem-cell homeostasis. Nat. Rev. Endocrinol. 11, 161-170. http://dx.doi. org/10.1038/nrendo.2014.208. 